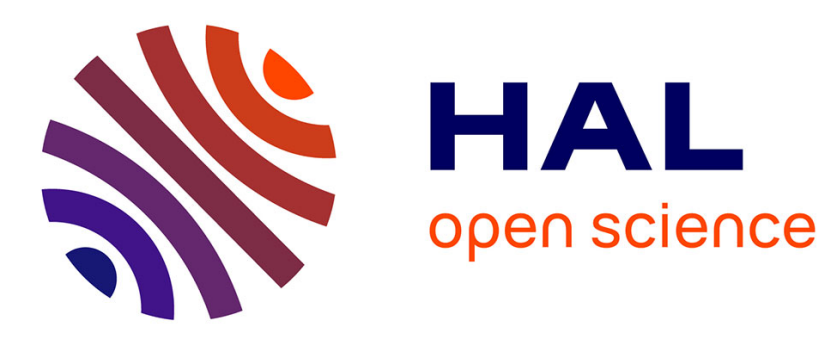

\title{
Nitrogen oxides measurements in an Amazon site and enhancements associated with a cold front
}

\author{
A. M. Cordova, K. Longo, S. Freitas, L. V. Gatti, P. Artaxo, A. Procópio, M.
}

A. F. Silva Dias, E. D. Freitas

\section{- To cite this version:}

A. M. Cordova, K. Longo, S. Freitas, L. V. Gatti, P. Artaxo, et al.. Nitrogen oxides measurements in an Amazon site and enhancements associated with a cold front. Atmospheric Chemistry and Physics Discussions, 2004, 4 (3), pp.2301-2331. hal-00303899

\section{HAL Id: hal-00303899 \\ https://hal.science/hal-00303899}

Submitted on 4 May 2004

HAL is a multi-disciplinary open access archive for the deposit and dissemination of scientific research documents, whether they are published or not. The documents may come from teaching and research institutions in France or abroad, or from public or private research centers.
L'archive ouverte pluridisciplinaire HAL, est destinée au dépôt et à la diffusion de documents scientifiques de niveau recherche, publiés ou non, émanant des établissements d'enseignement et de recherche français ou étrangers, des laboratoires publics ou privés. 
Nitrogen oxides measurements in an

Amazon site

\section{Nitrogen oxides measurements in an Amazon site and enhancements associated with a cold front}

A. M. Cordova ${ }^{1,2,3}$, K. Longo ${ }^{4}$, S. Freitas ${ }^{4}$, L. V. Gatti ${ }^{1}$, P. Artaxo ${ }^{5}$, A. Procópio ${ }^{2,5}$, M. A. F. Silva Dias $^{2,4}$, and E. D. Freitas ${ }^{2}$

${ }^{1}$ Instituto de Pesquisas Energéticas e Nucleares (IPEN), São Paulo, Brazil

${ }^{2}$ Instituto de Astronomia, Geofísica e Ciências Atmosféricas, Universidade de São Paulo, Brazil

${ }^{3}$ Centro de Estudios Avanzados en Zonas Áridas (CEAZA), Unidad Regional de Desarrollo Científico \& Tecnológico, La Serena, Chile

${ }^{4}$ Centro de Previsão de Tempo e Estudos Climáticos, INPE, Cachoeira Paulista, Brazil

${ }^{5}$ Instituto de Física, Universidade de São Paulo, São Paulo, Brazil

Received: 3 November 2003 - Accepted: 8 April 2004 - Published: 4 May 2004

Correspondence to: A. M. Cordova (acordova@intihuasi.inia.cl)

\section{A. M. Cordova et al.}

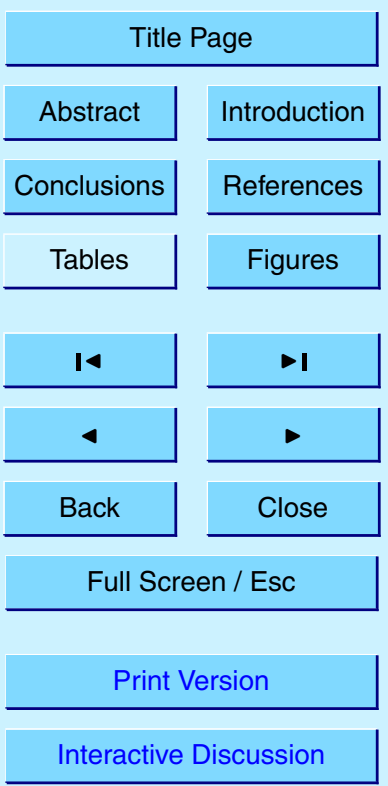

(C) EGU 2004 


\section{Abstract}

An intensive atmospheric chemistry study was carried out in a pristine Amazonian forest site (Balbina), Amazonas state, Brazil during the 2001 wet season, as part of the LBA/CLAIRE 2001 (The Large Scale Biosphere Atmosphere Experiment in Amazo5 nia/Cooperative LBA Airborne Regional Experiment) field campaign. Measurements of nitrogen oxide $(\mathrm{NO})$, nitrogen dioxide $\left(\mathrm{NO}_{2}\right)$ and ozone $\left(\mathrm{O}_{3}\right)$ were performed simultaneously with aerosol particles and black carbon concentrations and meteorological parameters observations. Very low trace gases and aerosol concentrations are typically observed at this pristine tropical site. During the measurement period, there was

a three-day episode of enhancement of $\mathrm{NO}_{2}$ and black carbon concentration. $\mathrm{NO}_{2}$ concentration reached a maximum value of $4 \mathrm{ppbv}$, which corresponds to three times the background concentration observed for this site. Black carbon concentration increased from the approximated $100 \mathrm{ng} / \mathrm{m}^{3}$ average value to a $200 \mathrm{ng} / \mathrm{m}^{3}$ maximum during the same period. Biomass burning spots were detected southward, between latitudes 15 Biomass Burning Algorithm). An atmospheric numerical simulation of the whole measurement period was carried out using the RAMS model coupled to a biomass burning emission and transport model. The simulation results pictured a smoke transport event from Central Brazil associated to an approach of a mid-latitude cold front, reinforcing the hypothesis of biomass burning products being long-range transported from the South by the cold front and crossing the Equator. This transport event shows how the pristine atmosphere pattern in Amazonia is impacted by biomass burning emissions from sites very far away.

\section{Introduction}

25 The study of $\mathrm{NO}, \mathrm{NO}_{2}$ and $\mathrm{O}_{3}$ trace gas over tropical forests is fundamental to our understanding of the dynamics of trace gases in tropical pristine conditions (Crutzen
ACPD

4, 2301-2331, 2004

\section{Nitrogen oxides} measurements in an Amazon site

A. M. Cordova et al.

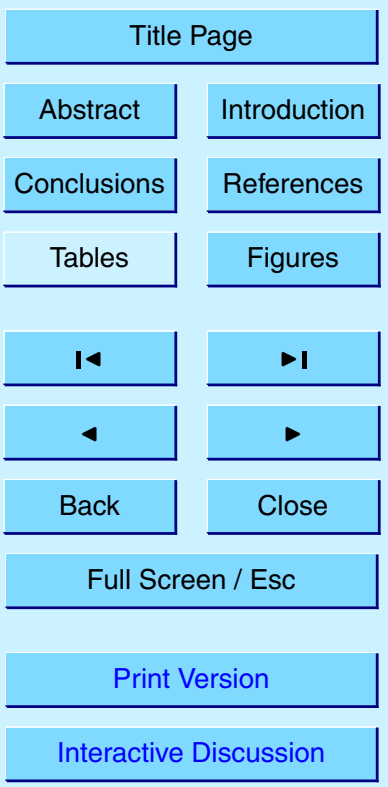

(C) EGU 2004 
and Andreae, 1990). The ratio $\mathrm{NO} / \mathrm{NO}_{2}$ is a critical ingredient in the mechanisms regulating ozone and hydroxyl radical $(\mathrm{OH})$ levels. The study of $\mathrm{NO}_{\mathrm{x}}\left(\mathrm{NO}_{\mathrm{x}}=\mathrm{NO}+\mathrm{NO}_{2}\right)$ provides information about microbiological activity in the soil and the nitrogen cycling in undisturbed forest ecosystems. The predominant natural source of NO is the mi5 crobial soil activity through nitrification process, and this emission depends on a combination of factors such as soil temperature, water, nutrients, $\mathrm{pH}$ and vegetation and atmospheric conditions (Davidson et al., 1992, 2000; Cardenas et al., 1993). The lifetime of odd nitrogen in the atmosphere is short, and background levels of atmospheric odd nitrogen are believed to be low in most of the tropical atmosphere (Kaplan et al., 10 1988). Additionally, NO is also formed in situ in the troposphere from lightning activities (Atkinson, 2000). Measurements of $\mathrm{NO}_{x}$ in the atmospheric boundary layer and lower free troposphere in remote maritime sites have generally yielded mixing ratios of 0.02 to $0.04 \mathrm{ppb}$. Mixing ratios in remote tropical forests appears to range from 0.02 to $0.08 \mathrm{ppb}$; the somewhat higher $\mathrm{NO}_{\mathrm{x}}$ concentrations found in the tropical forest, as 15 compared with those observed in remote marine locations, could result from biogenic $\mathrm{NO}_{\mathrm{x}}$ emissions from soil (Seinfeld and Pandis, 1998).

Ozone in the tropical troposphere plays a key role in determining the oxidizing power of the global atmosphere. Ozone is produced in the troposphere by oxidation of volatile organic compounds (VOCs) and CO in the presence of nitrogen oxides and solar radiation (Atkinson, 2000; Thompson et al., 2001). High UV and humidity in the tropics promote the formation of $\mathrm{OH}$ radicals from the $\mathrm{O}_{3}$ photolysis (Thompson et al., 1994, 1997; Jacob et al., 1996; Crutzen et al., 2000). Typical mid-day ozone concentrations in pristine areas are around 10-20 parts per billion by volume (ppbv)(Kirchhoff et al., $1988,1996)$ over the Amazon Basin. The net production of ozone could occur with NO 25 mixing ratio as low as 5 parts per trillion by volume (pptv) (Seinfeld and Padis, 1998). In the Amazon, the oxidation of $\mathrm{NO}$ to $\mathrm{NO}_{2}$ by organic peroxy radicals would likely contribute significantly to the ozone production.

Biomass burning is also an important source of trace gases to the Amazon atmosphere during the dry season (Browell et al., 1996; Andreae et al., 2001, 2002; Artaxo

ACPD

4, 2301-2331, 2004

Nitrogen oxides measurements in an Amazon site

A. M. Cordova et al.

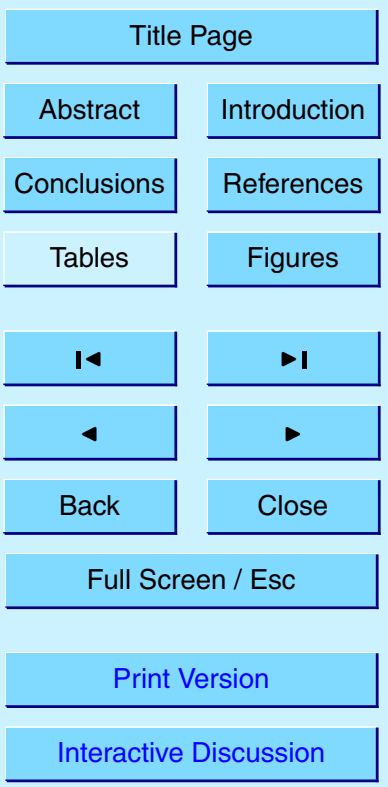

(C) EGU 2004 
et al., 2002). Biomass burning emits water vapor, carbon dioxide $\left(\mathrm{CO}_{2}\right)$, carbon monoxide $(\mathrm{CO})$, reactive odd nitrogen $\left(\mathrm{NO}_{\mathrm{y}}=\mathrm{NO}+\mathrm{NO}_{2}+\right.$ products of oxidation of $\left.\mathrm{NO}_{\mathrm{x}}\right)$, hydrocarbons and many other important species (Ferek et al., 1998; Andreae and Merlet, 2001). The aerosol particles emitted by biomass burning activities are very efficient in 5 absorbing and scattering solar radiation, and act as cloud condensation nuclei, playing an important role in the atmospheric radiation balance (Roberts et al., 2002; Procópio et al., 2004).

As part of the LBA/CLAIRE 2001 experiment, measurements of $\mathrm{NO}, \mathrm{NO}_{2}$ and $\mathrm{O}_{3}$ were performed in an Amazonian forest site from 11 June to 28 July 2001. The goals 10 of the experiment included understanding the role played by the changes of the trace gases concentrations in remote areas due to long range transport of pollutants. A complementary study of the pollutant transport mechanism was performed using a tracer transport model coupled to the Regional Atmospheric Modeling System - RAMS (Walko et al., 2000). The tracer transport simulation is made simultaneously, on-line 15 Wit with the atmospheric state evolution. This model approach was designed to study the transport of biomass burning emissions in the South American and African continents and a complete model description can be found in Freitas et al. (2004).

\section{Experiments and analytical methods}

The measurement site was at the Limnology Laboratory $\left(1^{\circ} 55.20^{\prime} \mathrm{S}, 59^{\circ} 28.07^{\prime} \mathrm{W}\right)$, lo20

\section{State of Amazon, Brazil (Fig. 1). The climate of this region is tropical, rainy and warm}

cated at the Hydroelectric Power Plant of Balbina, $150 \mathrm{~km}$ North of Manaus, in the during summer. The dry season occurs from June to November and the wet season from December to May. The red-yellow podzolicos soil predominates in nearly the whole region and is nutrient-poor, with elevated acidity and reduced natural fertility,

not suitable for agricultural use. The predominant vegetation is tropical rainforest with few deforested areas composed by cerrado (Brazilian savanna), flooded and unflooded forests. Ground elevations at the site average $90 \mathrm{~m}$ above mean sea level (MSL), while

ACPD

4, 2301-2331, 2004

\section{Nitrogen oxides measurements in an Amazon site}

A. M. Cordova et al.

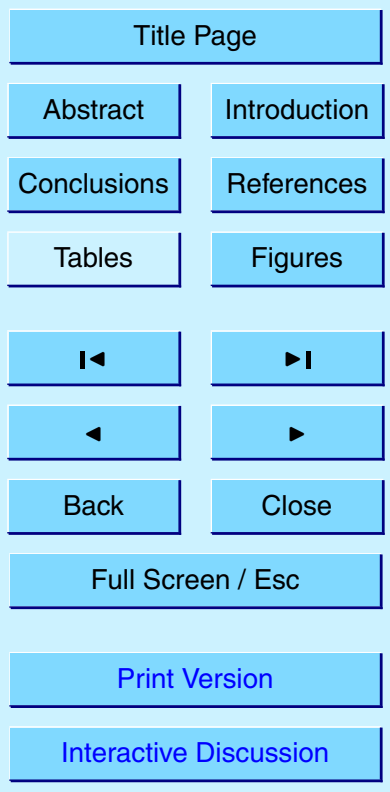

(C) EGU 2004 
the height of the forest canopy is about $30 \mathrm{~m}$ from surface.

Concentrations of $\mathrm{NO}, \mathrm{NO}_{2}$ and $\mathrm{O}_{3}$ were measured using a Teflon tube ( $2 \mathrm{~cm}$ dia.) of total length of $14 \mathrm{~m}$, continuously purging air by an auxiliary pump. A rain protected sampling head was mounted at $14 \mathrm{~m}$ above the surface. Air was drawn through $47 \mathrm{~mm}$ 5 PTFE-filters $\left(0.5 \mu \mathrm{m}\right.$ pore size) and $\frac{1}{4}^{\prime \prime}$ PTFE-tubing mounted on the sample intake ports of $\mathrm{NO} / \mathrm{NOx}$ and $\mathrm{O}_{3}$ analyzers. Commercial gas-phase-chemiluminescence and spectrometric analyzer (model Thermo Environmental Instruments Inc.) were used to measure the trace gases. Calibration was conducted with the use of a Thermo Environmental Instruments Inc., Model 146C Gas Phase Titration \& Ozone Generator. The $10 \mathrm{O}_{3}$ and $\mathrm{NO}_{\mathrm{x}}$ measurements were performed at every five and one minute, respectively.

Stacked filter units (SFU) fitted with a $\mathrm{PM}_{10}$ inlet was used for aerosol sampling (Hopke et al., 1998; Artaxo et al., 1998, 2002). The trace elements concentrations for the SFU samples were determined by Particle-induced X-Ray Emission (PIXE) analysis (Johansson and Campbell, 1995; Artaxo et al., 2002). It was possible to determine the concentrations of up to 16 elements (Al, Si, P, S, Cl, K, Ca, Ti, Cr, Mn, Fe, Ni, $\mathrm{Cu}, \mathrm{Zn}, \mathrm{Br}$, and $\mathrm{Pb}$ ). Mass concentration was obtained through gravimetric analysis and black carbon concentration of the fine fraction of the SFU filters was obtained by a light reflectance technique (Reid et al., 1998; Martins et al., 1998). A black carbon monitor, the aethalometer, manufactured by Magee Scientific Co, measured the black 20 carbon concentration. The aethalometer was operated with $5 \mathrm{~min}$ time resolution, and an absorption cross section of $10 \mathrm{~m}^{2} / \mathrm{g}$ was used to convert optical absorption to black carbon equivalent concentration (Martins et al., 1998; Artaxo et al., 1998).

Several balloons (Blimpworks, Statesville, NC, USA) were used during the CLAIRE 2001 in order to measure the aerosol profile (Greenberg et al., 2004). The number of 25 particle concentration $\left(\# / \mathrm{cm}^{3}\right)$ was measured with Particle Measuring System Abacus 301 instruments in four-size interval $(<0.3,0.3-0.5,0.5-1$ and $1-5 \mu \mathrm{m})$.

Radiation, temperature, relative humidity, winds speed and direction and pressure were measured at every five minutes, with a meteorological station located over a water tank $10 \mathrm{~m}$ above the ground. Wind vertical profiles up to a maximum height of

ACPD

4, 2301-2331, 2004

\section{Nitrogen oxides} measurements in an Amazon site

A. M. Cordova et al.

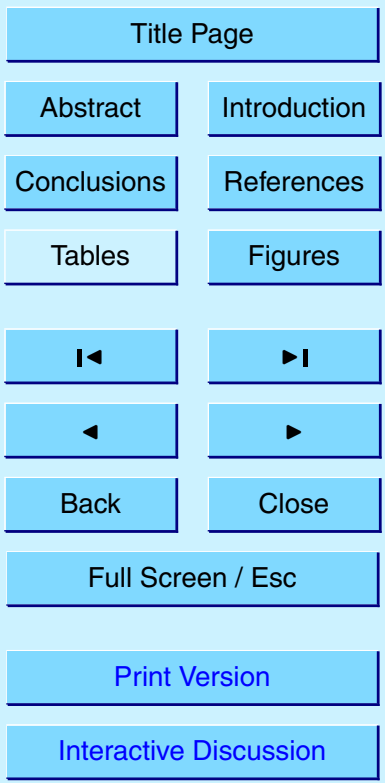

(C) EGU 2004 


\section{Results and discussions}

\subsection{Meteorological conditions}

5 The months of June and July typically correspond to the transition from the wet to the dry season in northern Brazil. During June 2001, the Intertropical Convergence Zone (ITCZ) contributed to the rain in the northern coast of Brazil with positive anomalies of precipitation extending from the coast to about $200-400 \mathrm{~km}$ inland. Conversely, in the Southwest and Northeast of the Amazon basin the precipitation was lower than

10 average. In July, the amount of rain was lower, compared to the June values, and below average on the northern part of the Amazon Basin extending to the northern coast of Brazil. During the field campaign, the total accumulated precipitation was of $250 \mathrm{~mm}$ at the experimental site.

In June, the approach of a mid-latitude cold front caused a climatological phe15 nomenon called friagem (Marengo et al., 1997a, b). A continental air mass that reached southern Brazil on 16 June, moved through the central region of Brazil and reached the Amazon Basin after three days (Fig. 1a). Figure 2a shows the geopotential height at $500 \mathrm{hPa}$ and Fig. $2 \mathrm{~b}$ the temperature and wind fields NCEP reanalysis at $925 \mathrm{hPa}$ for 20 June 2001 at 00:00 UTC. The southerly flow extends over most of western Brazil with the leading edge reaching the equator. The frontal boundary in the subtropics is associated with a well defined upper level geopotential trough with a cut off low over Uruguay. Low level cold air advection is located ahead of the $500 \mathrm{hPa}$ trough.

The cold air mass approach caused a strong decrease of temperature in the Amazon basin and was maintained up to 22 June. This friagem caused frost in southern and southeastern Brazil. Changes in the wind speed and direction and surface temperature

\section{Nitrogen oxides measurements in an Amazon site}

A. M. Cordova et al.

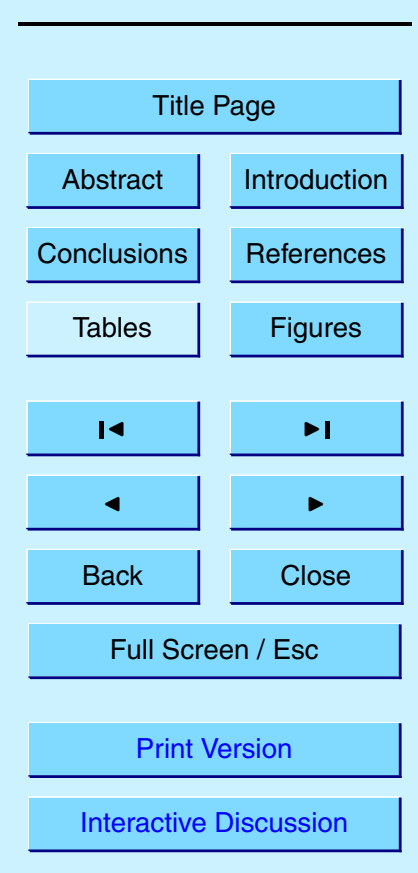

(c) EGU 2004 
and humidity values were observed in Balbina. Figure 3 shows the difference between average values of equivalent potential temperature $\left(\theta_{E}\right)$ for the CLAIRE 2001 period, excluding the days influenced by the cold front and the average for the days during the cold front. It is possible to observe a decrease of $\theta_{E}$ of $9 \mathrm{~K}$ at night and $14 \mathrm{~K}$ during 5 daytime. The cold front also caused a decrease in the amount of solar radiation reaching the surface at this site during this period, from 345 to $113 \mathrm{~W} / \mathrm{m}^{2}$ due cloudiness associated with it (Fig. 4). The vertical profile of the meridional winds from the SODAR shows an enhancement of the wind speed reaching 6 to $8 \mathrm{~m} / \mathrm{s}$, above $100 \mathrm{~m}$ altitude, during the cold front (Fig. 5a), also with an increase in the wind shear (Fig. 5b). These 10 changes were observed only for this episode during the whole period of the campaign. The change in the direction of the air mass origin was also correctly captured by the atmospheric numerical simulation of the period using the RAMS model. Backward trajectories from Balbina, for the previous day of the cold front arrival show the air mass originating from the Atlantic Ocean, as can be seen in Fig. 6a. During the cold front 15 approach period, the backward trajectories show different origins of the air parcels, coming from South and Southeast Brazil (Fig. 6b).

\subsection{Trace gases}

Figure 7a shows the time series for $\mathrm{NO}$ and $\mathrm{NO}_{2}$ mixing ratio from 11 June to 25 July 2001. $\mathrm{NO}_{2}$ concentrations were higher than $\mathrm{NO}$ concentrations during all the study 20 period, with NO concentration below $1.0 \mathrm{ppb}$. During the cold front period, an increase of $\mathrm{NO}_{2}$ concentration was observed, with the maximum concentration of $4 \mathrm{ppb}$, during the night of 19 and 20 July. On the other hand, no significant change of NO was observed in association to the $\mathrm{NO}_{2}$ enhancement. The $\mathrm{O}_{3}$ concentrations were always below $25 \mathrm{ppb}$, which is characteristic of pristine areas (Kirchhoff et al., 1988; Betts et 25 al., 2002). A decrease of the $\mathrm{O}_{3}$ concentration was observed during the cold front episode, probably due the decrease in the incident solar radiation (Fig. 7b).

To show the effect of the cold front in the trace gases concentration, the campaign was splitted up in two periods based on the $\mathrm{NO}_{2}$ concentrations. Period named
ACPD

4, 2301-2331, 2004

Nitrogen oxides measurements in an Amazon site

A. M. Cordova et al.

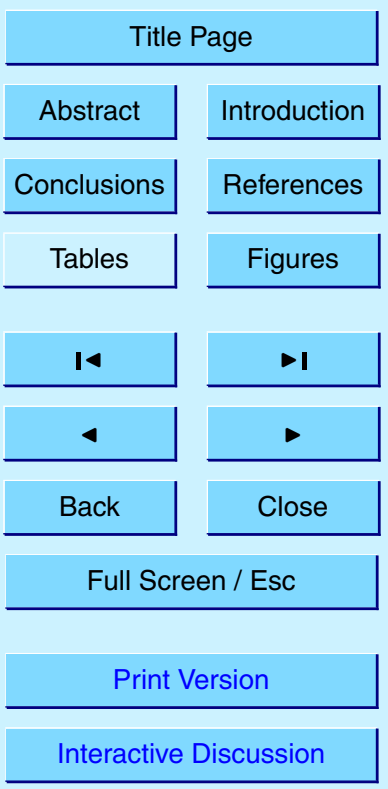

(c) EGU 2004 
CLAIRE 2001 considers all days of campaign, excluding the days influenced by the cold front, and conversely, the called cold front episode includes the days from 19 to 22 June. Figures 8 and 9 show the average diurnal variation of $\mathrm{NO}, \mathrm{NO}_{2}$ and $\mathrm{O}_{3}$ obtained for these two periods. Figure 8 a shows the average NO concentration during CLAIRE 52001 presenting an increase during the first hours of the day, which could be a result of the accumulation of NO emitted at night (De Serve et al., 1996) and the photolysis of the accumulated nocturnal $\mathrm{NO}_{2}$ produced by the reaction of $\mathrm{NO}$ and $\mathrm{O}_{3}$ after sunset. After sunrise, the turbulent mixing in the convective boundary layer causes the dispersion of gases, reducing their concentrations. During the cold front episode, the 10 average NO concentration was similar to CLAIRE 2001, but the diurnal cycle shows no night accumulation of NO; this could indicate a lower emission from the soil due to the lower surface temperature observed in this period (Fig. 3). On the other hand, during the cold front the NO concentration sunlight time was slightly higher than it was for CLAIRE 2001, which could be a response to the $\mathrm{NO}_{2}$ photolysis inhibition due to the lower solar radiation availability in this period (Fig. 4).

The diurnal cycle of $\mathrm{NO}_{2}$ concentration during CLAIRE 2001 period presented an average of $0.35 \mathrm{ppb}$ at night, reaching the minimum concentration of $0.2 \mathrm{ppb}$ at $13: 00$ 14:00 LT (Fig. 8b), due to the maximum solar radiation availability. A decrease in $\mathrm{NO}_{2}$ concentrations during the first hours of the day was observed, because of the photolysis of $\mathrm{NO}_{2}$ that also caused an increase of the $\mathrm{NO}$ concentration (Fig. 8a). During the day, $\mathrm{NO}_{2}$ concentration decreased due to photolysis, reactions with $\mathrm{OH}$ radical to form $\mathrm{HNO}_{3}$ (Fuglestvedt et al., 1994) and dispersion caused by turbulent processes. Average $\mathrm{NO}_{2}$ concentrations during the cold front episode were similar to CLAIRE 2001, but at 18:00 LT an increase of up to $1.8 \mathrm{ppb}$ was observed, with maximum instant concentration of $4 \mathrm{ppb}$. This increased concentration can be a result of regional transport associated with the frontal system that also caused changes in the wind directions and increased the wind speed and wind shear (Fig. 5).

Figure 9 shows ozone diurnal variations for the two periods with minimum concentrations at night and maximum concentrations during daytime. During the CLAIRE 2001

ACPD

4, 2301-2331, 2004

Nitrogen oxides measurements in an Amazon site

A. M. Cordova et al.

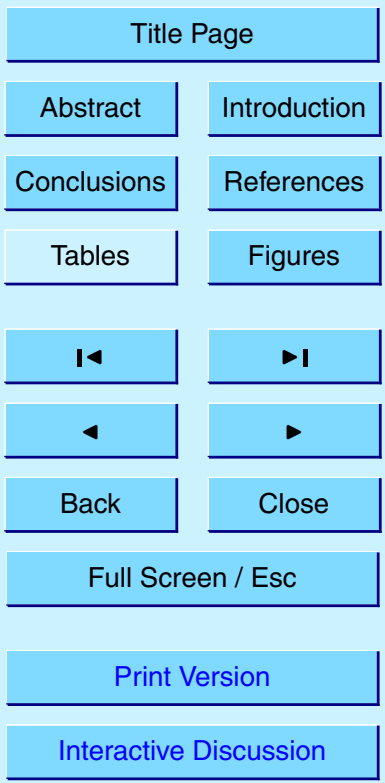

(C) EGU 2004 
period, the average day maximum of $14.5 \mathrm{ppb}$ was reached around 12:00-15:00 LT, while the average ozone concentration at night was around $3.2 \mathrm{ppb}$. During the cold front, average ozone concentration was two times lower than daytime average value for the CLAIRE 2001, although at night the $\mathrm{O}_{3}$ concentrations were comparable for 5 both periods. The low photochemical production of ozone during the cold front can be related to the high cloud cover, which inhibits solar radiation reaching the surface (Fig. 4). The lower ozone concentration can also be due to the lower volatile organic compounds (VOCs) concentrations. The VOCs react with $\mathrm{NO}_{\mathrm{x}}$ to form $\mathrm{O}_{3}$, but the emission of VOCs also depends on temperature and radiation availability (Guenther 10 et al., 1995). During the cold front, the decrease of temperature and radiation can be responsible for the low emission of VOCs, which in turn causes a decrease in the photochemical production of $\mathrm{O}_{3}$.

\subsection{Aerosol}

Figure 10 shows black carbon concentration for CLAIRE 2001 and cold front periods. 15 Black carbon presented a similar behavior of the $\mathrm{NO}_{2}$. The average black carbon concentration during CLAIRE 2001 was $92 \mathrm{ng} / \mathrm{m}^{3}$, with no clear diurnal cycle. During the cold front episode, black carbon concentration showed an increase after sunset reaching the maximum concentration of $224 \mathrm{ng} / \mathrm{m}^{3}$. The filters sampled between 19 and 21 June at nighttime presented about $12.3 \%$ of black carbon in the fine mode particulate material (Fig. 11). This ratio was the highest for the all campaign. This increase in black carbon reinforces the suspicion of a transport of biomass burning products from the South advected by the frontal system. An increase in the particulate matter coarse mode of the aerosol particle concentration was also observed during the cold front episode. The analysis of the sampled filters shows an increase of soil dust

Aerosol vertical profiles were obtained in the balloon experiment. Figure 13 shows the profiles measured at 11:00 LT for the days before the arrival of the cold front (14, 16 and 18 June) and during the cold front (19, 20 and 21 June). The aerosol parti-

ACPD

4, 2301-2331, 2004

Nitrogen oxides measurements in an Amazon site

A. M. Cordova et al.

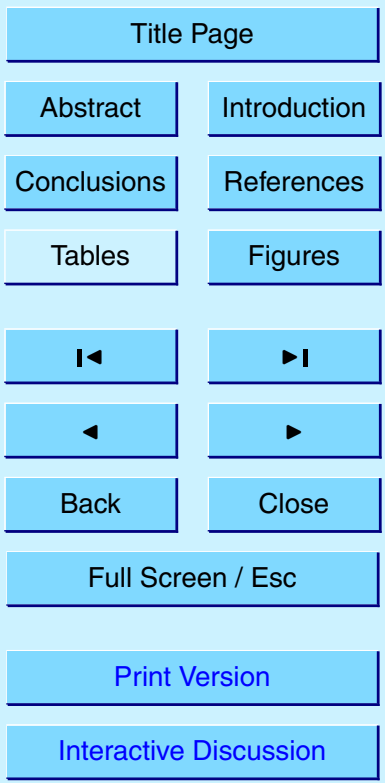

(C) EGU 2004 
cle number concentration decreases with the increase of the particle size for all days. The profile of concentration of aerosol particles with diameter smaller than $0.5 \mu \mathrm{m}$ increased with altitude, while the concentration for larger particles $\left(0.5<\mathrm{d}_{p}<1 \mu \mathrm{m}\right.$ and $1<\mathrm{d}_{p}<5 \mu \mathrm{m}$ ) was constant with altitude. Differences in the aerosol concentration were 5 observed between the days before and during the cold front. The aerosol profiles of particles with diameter less than $0.5 \mu \mathrm{m}$ showed concentrations three times higher during the cold front than during the previous days, while larger particle profiles did not show a significant difference between the two periods.

The increase of $\mathrm{NO}_{2}$ and black carbon suggested products of biomass burning. Al10 though burning activities were not detected nearby the study area in June, the fire product from the GOES-8 WFABBA (Prins et al., 1998) indicated hot spots from biomass burning in the southern portion of the study area (Fig. 14), which could be the possible source of the high $\mathrm{NO}_{2}$ and aerosols concentrations measured at Balbina during a cold front approach.

15 3.4. Model results

This section describes the role of a mid-latitude cold front approaching the Amazon basin on 20 and 21 June, on the polluted air mass transport to pristine areas in the Amazon using a numerical simulation with RAMS and the on-line biomass burning emission and transport model (Freitas et al., 2004). Although June and July is a transition period between wet to dry season, the biomass burning fires in the cerrado and pasture areas in Central Brazil start earlier in the biomass burning season. Particularly on 15 June many fires were detected in this area by the GOES-8 WF_ABBA fire product (Fig. 14). Figure 15a presents the model results for particulate material $(\mathrm{dp}<2.5 \mu \mathrm{m}$, PM2.5) vertically integrated $\left(\mathrm{mg} / \mathrm{m}^{2}\right.$ ) on 16 June and Fig. $15 \mathrm{~b}$ a vertical cross section 25 of PM2.5 concentration $\left(\mu \mathrm{g} / \mathrm{m}^{3}\right)$ at longitude $59.5 \mathrm{~W}$, depicting the atmospheric pollutants from biomass burning located closed to the fires. Figure 16 shows the same pictures for 21 June. As can be seen, at that time the pollutants were transported by the circulation associated with the cold front system to the North of the Amazon. The

\section{Nitrogen oxides measurements in an Amazon site}

A. M. Cordova et al.

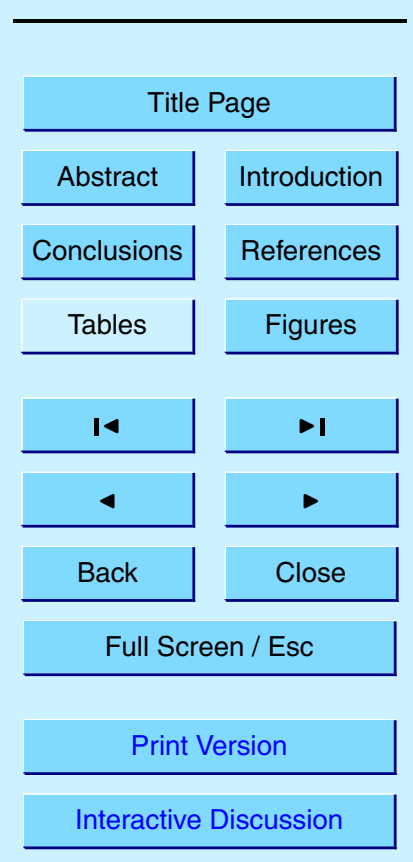


most evident effect of the cold front approaching Central Brazil and the Amazon is the northward transport of biomass burning pollutants. Following the cold front approach, the polluted air in Central South America is replaced by a clean and cold air behind it, and the smoke is then pushed into the Amazon basin changing the pristine air pat5 tern. During this event smoke transport was also observed at the Northwest Amazon, an area much more cloudy than Central Brazil. Less obvious is the effect of the associated convective systems on the smoke particulate and gaseous distribution, as it involves an enhancement of the vertical transport and precipitation and consequent smoke scavenging, including $\mathrm{NO}_{x}$ deposition (via soluble nitric acid). High troposphere 10 smoke input has been already observed associated with Northwest Amazon convective systems (Freitas et al., 2000).

\section{Conclusions}

The increase of the observed $\mathrm{NO}_{2}$, fine particles and black carbon concentrations at pristine areas of Amazon basin, reinforce the hypothesis of biomass burning products 15 being transported from the South by the cold front. Modeling results using backward trajectories calculation and a Eulerian tracer transport model have confirmed this hypothesis, linking enhancements of pollution signals at remote area of Amazon basin with fires activities at Central of Brazil.

Acknowledgements. This study was carried out as part of the Large-Scale Biosphere20 Atmosphere Experiment in Amazônia (LBA). The authors are thankful to FAPESP "Fundação de Amparo à Pesquisa do Estado de São Paulo" for financial support through the scholarship of A. M. Cordova, projects 01/05296-8 (K. Longo), 01/05025-4 (S. Freitas), and 97/11358-9 (L. V. Gatti and P. Artaxo). P. Artaxo also thanks to CNPq (Projeto Milnio) for financial support. Acknowledgments for A. Yamasaki, A. Pretto, W. C. Martins, A. C. Ribero, A. L. Ribeiro and T. 25 Germano assistance during the field campaign.
ACPD

4, 2301-2331, 2004

\section{Nitrogen oxides measurements in an Amazon site}

A. M. Cordova et al.

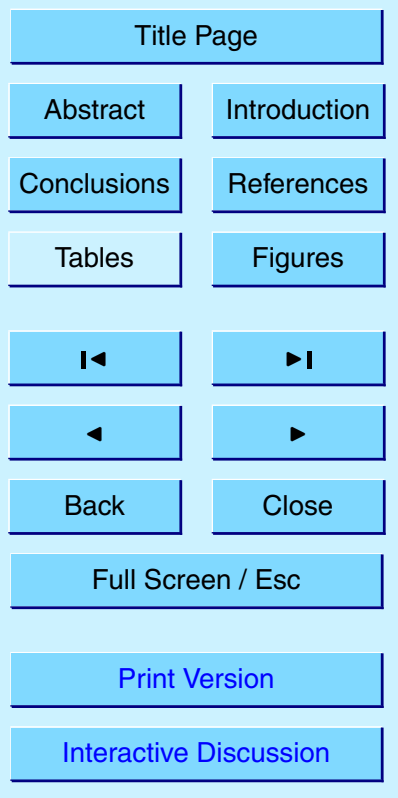

(c) EGU 2004 


\section{References}

Andreae, M. O., Artaxo, P., Fischer, H., Freitas, S. R., Grégoire, J.-M., Hansel, A., Hoor, P., Kormann, R., Krejci, R., Lange, L., Lelieveveld, J., Lindinger, W., Longo, K., Peters, W., de Reus, M., Scheeren, B., Silva-Dias, M. A. F., Strom, J., van Velthoven, P. F. J., and Williams, J.: Transport of biomass burning smoke to the upper troposphere by deep convection in the equatorial region, Geophys. Res. Lett., 28, 6, 951-954, 2001.

Andreae, M. O. and Merlet., P.: Emission of trace gases and aerosols from biomass burning, Global Biogeochemical Cycles, 15, 955-966, 2001.

Andreae, M. O., Artaxo, P., Brandão, C., Carswell, F. E., Ciccioli, P., da Costa, A. L., Culf, A. D., Esteves, J. L., Gash, J. H. C., Grace, J., Kabat, P., Lelieveld, J., Malhi, Y., Manzi, A. O., Meixner, F. X., Nobre, A. D., Nobre, C., Ruivo, M. d. L. P., Silva-Dias, M. A., Stefani, P., Valentini, R., von Jouanne, J., and Waterloo, M. J.: Biogeochemical cycling of carbon, water, energy, trace gases, and aerosols in Amazonia: The LBA-EUSTACH experiments, J. Geophys. Res., 107, (D20), 8066-8091, doi:10.1029/2001JD000524, 2002.

15 Artaxo, P., Martins, J. V., Yamasoe, M. A., Procópio, A. S., Pauliquevis T. M., Andreae, M. O., Guyon, P., Gatti, L. V., and Cordova, A. M.: Physical and chemical properties of aerosols in the wet and dry season in Rondonia, Amazonia, J. Geophys. Res., 107, (D20), 8081, doi:10.1029/2001JD000666, 2002.

Artaxo, P., Fernandes, E. T., Martins, J. V., Yamasoe, M. A., Hobbs, P. V., Maenhaut, W., Longo, K. M., and Castanho, A.: Large-scale aerosol source apportionment in Amazonia, J. Geophys. Res, 103, (D24), 31 837-31847, 1998.

Atkinson, R.: Atmospheric chemistry of VOCs and NOX, Atmos. Environ., 34, 2063-2101, 2000.

Betts, A., Gatti, L. V., Cordova, A. M., Silva-Dias, M. A. F., and Fuentes, M.: Transport of ozone to the surface by convective downdrafts at night, J. Geophys. Res., 107, (D20), doi:10,029/2000JD00158, 2002.

Browell, E. V. and Fenn, M. A.: Ozone and aerosol distributions and air mass characteristic over the south Atalantic basin during the burning season, J. Geophys. Res., 101, (D1), $24043-$ $24068,1996$.

30 Cardenas, L., Randon, A., Johanson, C., and Sanhueza, E.: Effects of soil moisture, temperature and inorganic nitrogen on nitric oxides emissions from acidic tropical savannah soil, J. Geophys. Res., 14783-14 790, 1993.
ACPD

4, 2301-2331, 2004

Nitrogen oxides

measurements in an

Amazon site

A. M. Cordova et al.

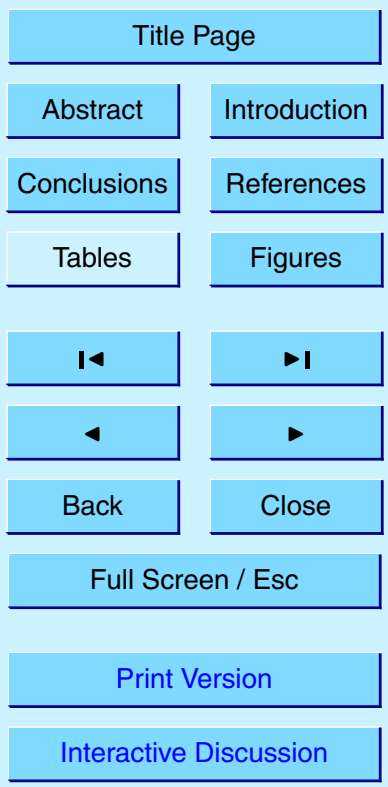

(C) EGU 2004 
Crutzen, P. J. and Andreae, M. O.: Biomass Burning in the Tropics: Impact on Atmospheric Chemistry et Biogeochemical Cycles, Science, 250, 1669-1678, 1990.

Crutzen, P. J., Williams, J., Hoor, P., Fischer, H., Warneke, R., Holzinger, R., Hansel, A., Lindinger, W., Scheeren, B., and Lelieveld, J.: High spatial and temporal resolution mea-

5 surement of primary organics and their oxidant products over the tropical forest of Surinam, Atmos. Environ., 34, 1161-1165, 2000.

Davidson, E. A., Keller, M., Erickson, H. E., Verchot, L. V., and Veldkamp, E.: Testing a conceptual model of soil emissions of nitrous and nitric oxides, BioScience, 50, 667-680, 2000.

Davison, E. A.: Sources of nitric oxide and nitrous oxide following welling of dry soil, Soil SC. Soc. Of Am. J., 56, 95-102, 1992.

De Serve, C., Rondon, A., and Oyola, P.: Photochemical studies in the savanna boundary layer during wet season, Atm. Environ., 30, 1419-1427, 1996.

Ferek, R. J., Reid, J. S., Hobbs, P. V., Blake, D. R., and Liousse, C.: Emission factors of hydrocarbons, halocarbons, trace gases and particles from burning in Brazil, J. Geophys. Res., 103, D24, 32 107-32 118, 1998.

Freitas, S. R., Silva-Dias, M. A. F., Silva-Dias, P. L., Longo, K. M., Artaxo, P., Andreae, M. O., and Fischer, H. A.: Convective kinematic trajectory technique for low-resolution atmospheric models, J. Geophys. Res., 105, (D19), 24 375-24 386, 2000.

Freitas, S. R., Longo, K. M., Silva-Dias, M. A. F., Silva-Dias, P. L., Chatfield, R., Prins, E., Artaxo, P., and Recuero, F. S.: Monitoring the Transport of Biomass Burning Emissions in South America, Environmental Fluid Mechanics, 5th RAMS Users Workshop Specia Issue, in press, 2004.

Fuglestvedt, J. S., Jonson, J. E., and Isaksen, I. S. A.: Effects of reduction in stratospheric ozone on tropospheric chemistry through changes in photolysis rates, Tellus, 46B, 172-192, 251994.

Greenberg, J. P., Guenther, A. B., Pétron, G., Wiedinmyer, C., Vega, O., and Gatti, L. V.: Biogenic VOC emissions from forest and cleared Amazonian landscapes, Global Change Biology, in press, 2004.

Guenther, A., Hewitt, C. N., Erickson, D., Fall, R., Geron, C., Graedel, T., Harley, P., Klinger, L., Lerdau, M., McKay, W. A., Pierce, T., Scholes, B., Steinbrecher, R., Tallamraju, R., Taylor, J., and Zimmerman, P. A.: Global model of natural volatile organic compound emissions, J. Geophys. Res., 100, 8873-8892, 1995.

Hopke, P. K., Xie, Y., Paatero, P., Barrie, L. A., and Li, S.-M.: Multiway analysis of airborne

\section{Nitrogen oxides measurements in an Amazon site}

A. M. Cordova et al.

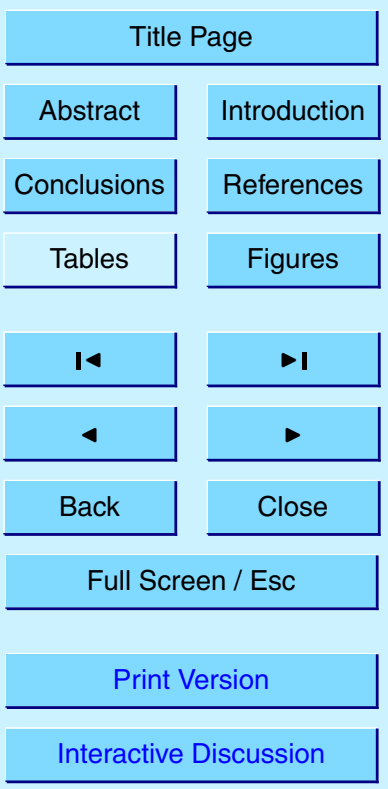

(C) EGU 2004 
particle composition data, J. Aerosol Sci., 29, 515-516, 1998.

Jacob, D. J. Heikes, B. G., Fan, S.-M., Logan, J. A., Mauzerall, D. L., Bradshaw, J. D., Singh, G. L., Gregory, G. L., Talbot, R. W., Balke, D. R., and Sachse, G. W.: The origin of ozone and NOx in the tropical troposphere: A photochemical analysis of aircraft observation over the South Atlantic basin, J. Geophys. Res., 101, (D2), 24 235-24 250, 1996.

Johansson, S. A. E., Campbell, J. L., and Malmqvist, K. G. (Eds.): Particle-Induced X-Ray Emission Spectrometry (PIXE), John Wiley, New York, 1995.

Kaplan, W. A., Wofsy, S. C., Keller, M., and da Costa, J. M.: Emission of NO and deposition of O3 in tropical forest system, J. Geophys. Res., 93, 1389-1395, 1998.

10 Kirchhoff, V. W. J. H.: Surface ozone measurements in Amazonia, J. Geophys. Res., 93, (D2), 1469-1476, 1988.

Kirchhoff, V. W. J. H. and Alvalá, P. C.: Overview of an aircraft expedition into the Brazilian cerrado for the observation of atmospheric trace gases, J. Geophys. Res., 101, (D19), 23 95723 982, 1996.

Marengo, J. A., Cornejo, A., Satyamurty, P., Nobre, C. A., and Sea, W.: Cold waves in the South American continent: The strong event of June 1994, Mon. Wea. Rev., 125, 27592786, 1997a.

Marengo, J. A., Nobre, C. A., and Culf, A. D.: Climatic impacts of the "friagens" in the Amazon region, J. Appl. Meteorol., 36, 1553-1566, 1997b.

20 Martins, J. V., Artaxo, P. Liousse, C., Reid, J. S., Hobbs, P. V., and Kaufman, Y.: Effects of black carbon content, particle size, and mixing on light absorption by aerosols from biomass burning in Brazil, J. Geophys. Res , 103, (D4), 32 041-32 050, 1998.

Prins, E. M., Feltz, J. M., Menzel, W. P., and Ward, D. E.: An overview of GOES-8 Diurnal Fire and Smoke Results for SCAR-B and 1995 Fire Season in South America, J. Geophys. Res., 103, D24, 31 821-31835, 1998.

Procópio, A. S., Artaxo, P., Kaufman, Y. J., Remer, L. A., Schafer, J. S., and Hollben, B. N.: Multiyear Analysis of Amazonian Biomass Burning Smoke Radiative Forcing of Climate, Geophys. Res. Lett., 31, L03108, doi:10.1029/2003GL018646, 2004.

Reid, J. S., Hobbs, P. V., Liousse, C., Martins. J. V., Weiss, E., and Eck, T. F.: Comparisons of techniques for measuring shortwave absorption and black carbon content of aerosols from biomass burning in Brazil, J. Geophys. Res., 103, (D24), 32 031-32 040, 1998.

Roberts, G., Artaxo, P., Zhou, J., Swietlicki, E., and Andreae, M. O.: Sensitivity of CCN spectra on chemical and physical properties of aerosol: a case study from the Amazon Basin, J.
ACPD

4, 2301-2331, 2004

Nitrogen oxides

measurements in an

Amazon site

A. M. Cordova et al.

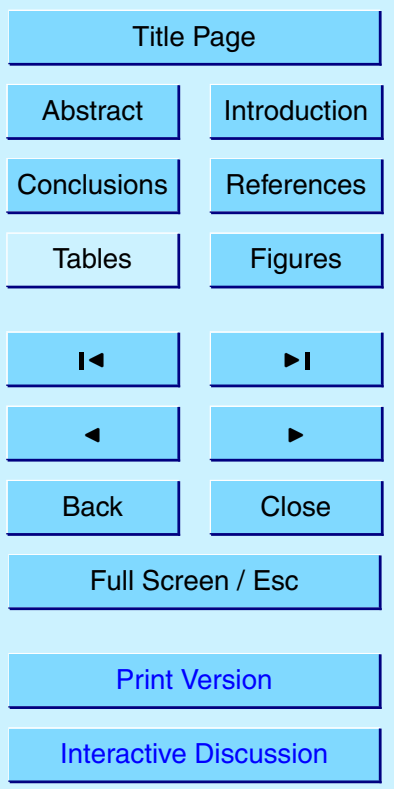

(C) EGU 2004 
Geophys. Res., 107, doi:10.1029/2001JD000583, 2002.

Seinfeld, J. H. and Pandis, S. N.: Atmospheric composition, global cycles, and lifetime, In: "Atmospheric chemistry and physics: from air pollution to climate change", edited by John Wiley \& Sons Inc., USA, 49-124, 1998.

5 Thompson, A. M.: Oxidants in the unpolluted marine atmosphere, Environmental Oxidants, edited by Nriagu, J. O. and Simmons, M. S., pp. 31-61, John Wiley, New York, 1994.

Thompson, A. M., Tao, W.-K., Pickering, K. E., Scala, J. R., and Simpson, J.: Tropical deep convection and ozone formation, Bull. Amer. Meteor. Soc., 78, 1043-1054, 1997.

Thompson, A. M., Witte, J. C., Hudson, R. D., Guo, H., Herman, J. R., and Fujiwara, M.: Tropical tropospheric ozone and biomass burning, Science, 291, 2128-2132, 2001.

Walko, R., Band, L., Baron, J., Kittel, F., Lammers, R., Lee, T., Ojima, D., Pielke, R., Taylor, C., Tague, C., Tremback, C., and Vidale, P.: Coupled atmosphere-biophysics-hydrology models for environmental modeling, J. Appl. Meteorol, 39, (6), 931-944, 2000.

\section{ACPD}

4, 2301-2331, 2004

Nitrogen oxides measurements in an Amazon site

A. M. Cordova et al.

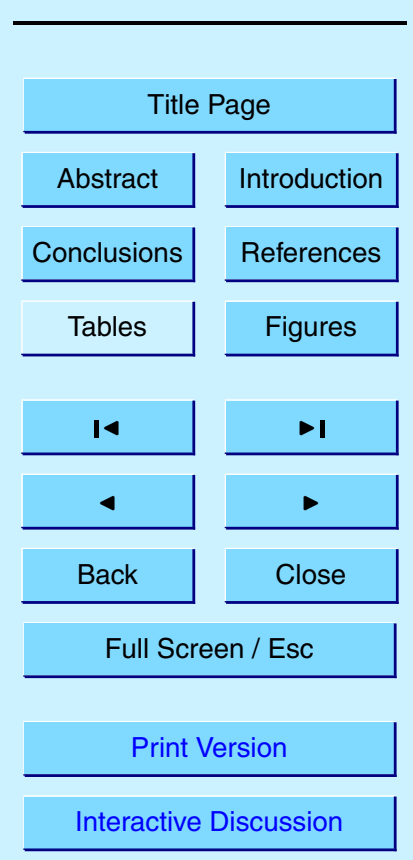

(C) EGU 2004 


\section{ACPD}

4, 2301-2331, 2004

Nitrogen oxides measurements in an Amazon site
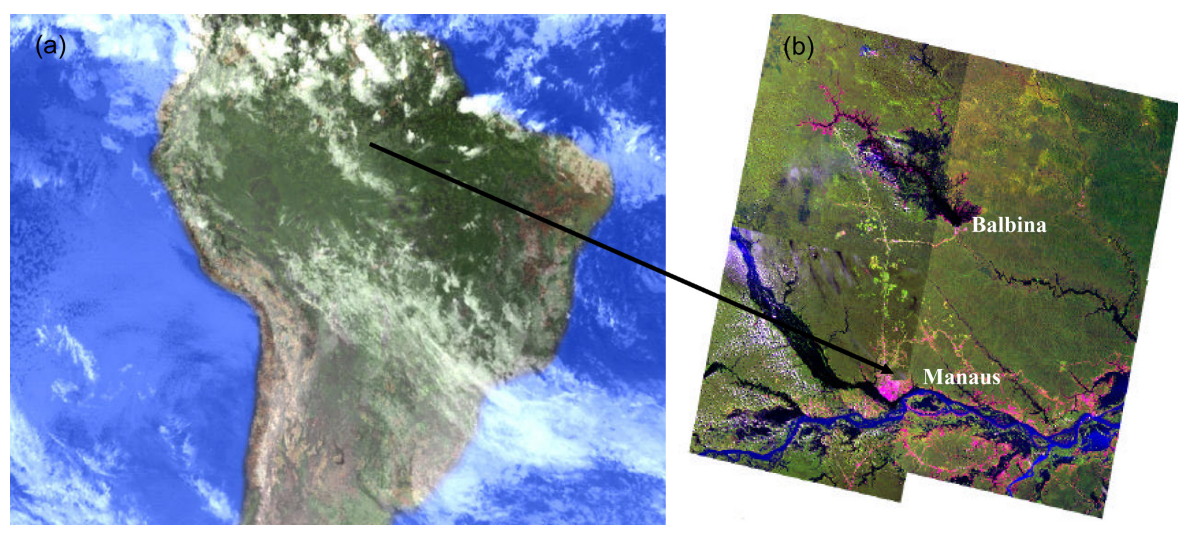

Fig. 1. (a) GOES-8 satellite infrared images for 19 June 2001 at $22: 45$ UTC and (b) view of Manaus and Balbina.
A. M. Cordova et al.

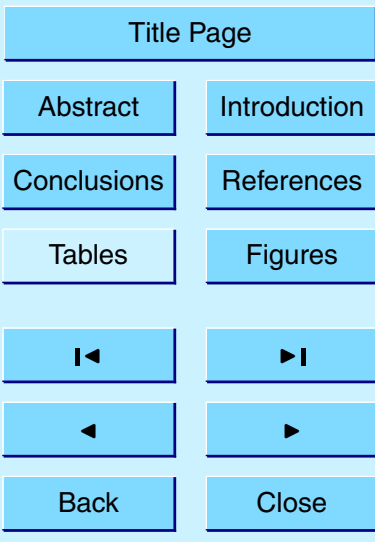

Full Screen / Esc

Print Version

Interactive Discussion

(C) EGU 2004 


\section{ACPD}

4, 2301-2331, 2004
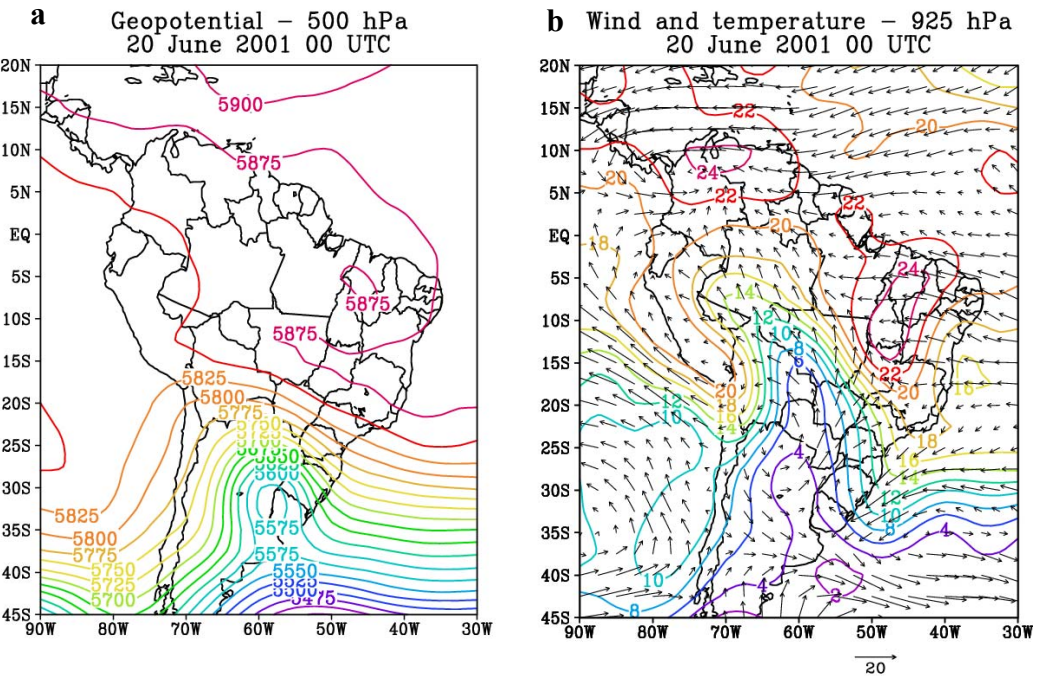

\section{Nitrogen oxides measurements in an Amazon site}

A. M. Cordova et al.

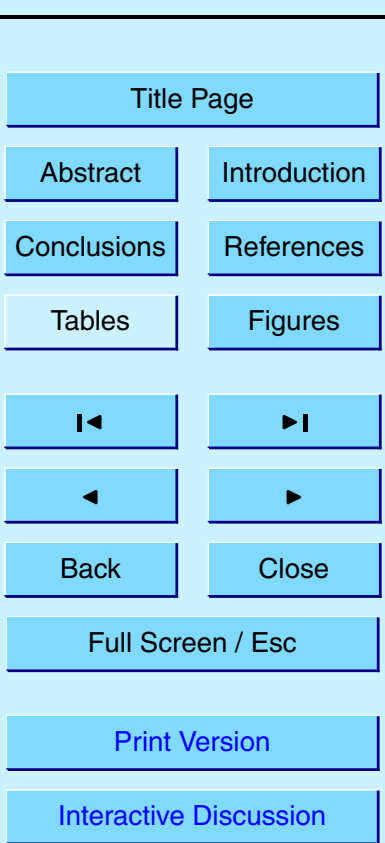

Fig. 2. NCEP reanalysis for (a) geopotential height $(\mathrm{m})$ at $500 \mathrm{hPa}$ and $(\mathbf{b})$ temperature $\left({ }^{\circ} \mathrm{C}\right)$

Interactive Discussion

(c) EGU 2004 


\section{ACPD}

4, 2301-2331, 2004

Nitrogen oxides measurements in an Amazon site

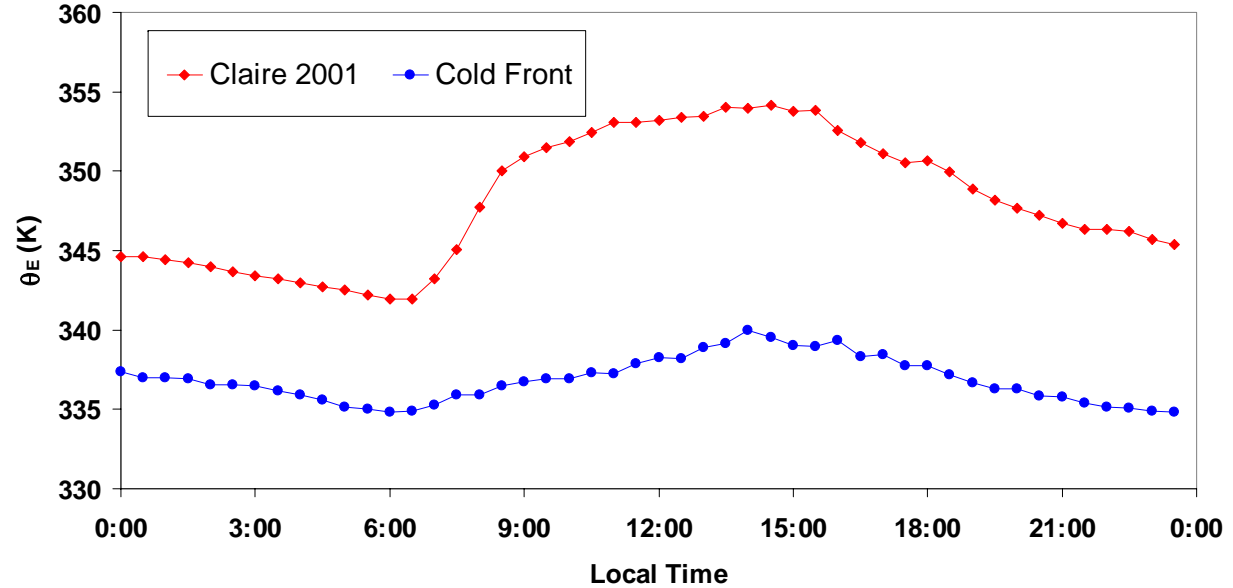

Fig. 3. Average equivalent potential temperature for CLAIRE 2001 and cold front periods measured in Balbina during the LBA-CLAIRE 2001.
A. M. Cordova et al.

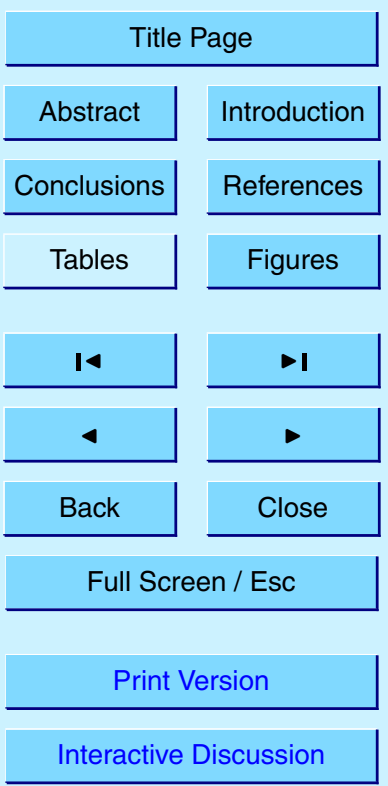

(C) EGU 2004 


\section{ACPD}

4, 2301-2331, 2004

Nitrogen oxides measurements in an Amazon site

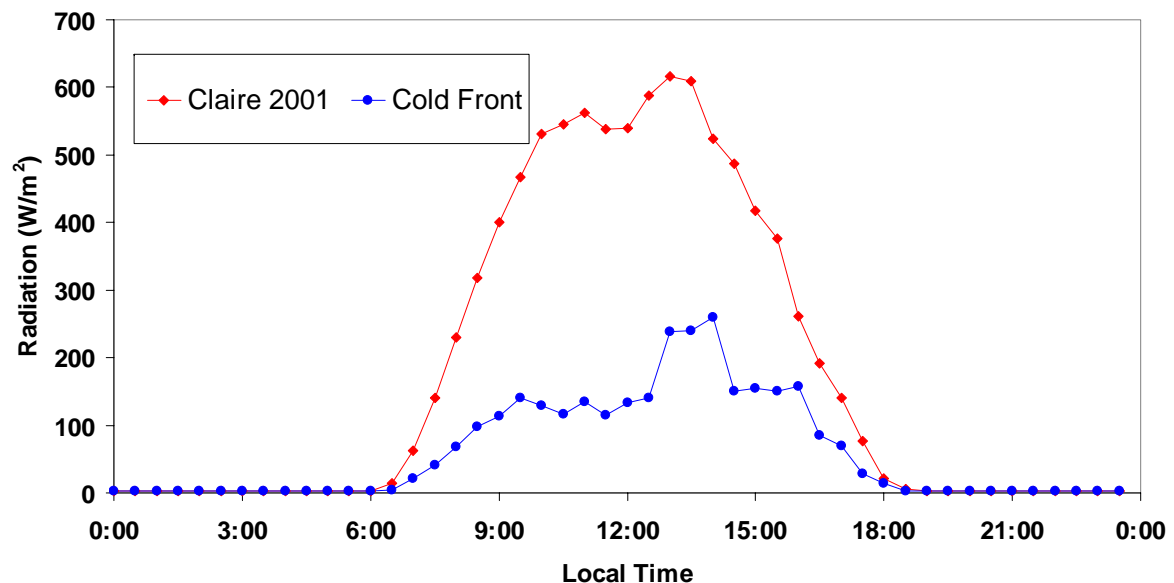

A. M. Cordova et al.

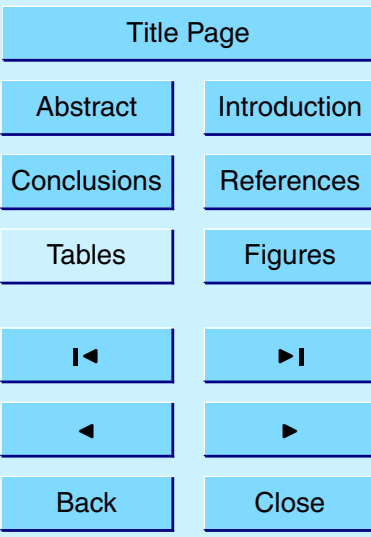

Fig. 4. Average radiation for CLAIRE 2001 and cold front periods measured in Balbina during LBA-CLAIRE 2001.

Full Screen / Esc

Print Version

Interactive Discussion

(C) EGU 2004 


\section{ACPD}
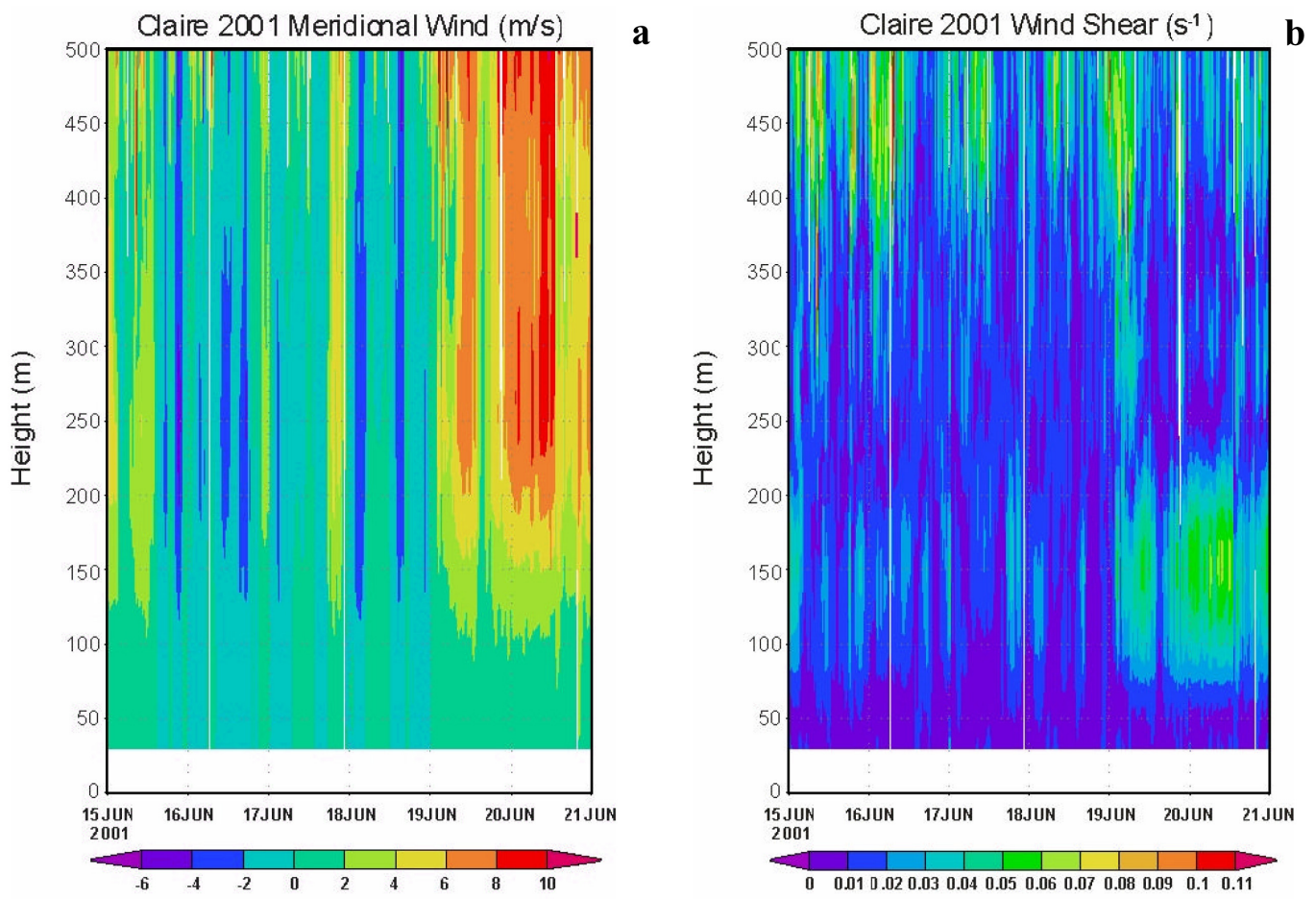

4, 2301-2331, 2004

Nitrogen oxides measurements in an Amazon site

A. M. Cordova et al.

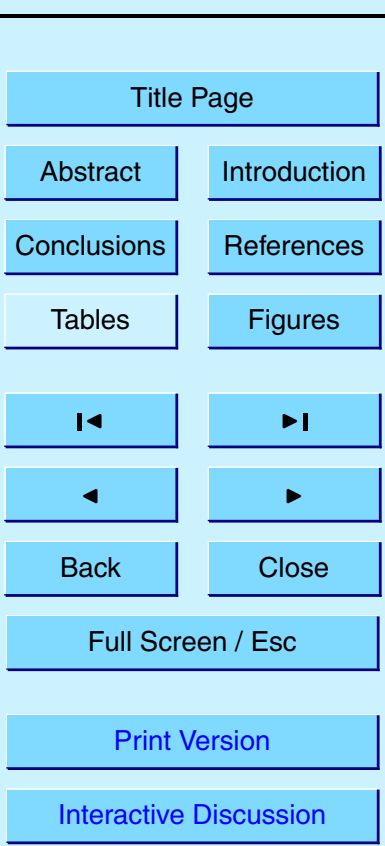

(C) EGU 2004 


\section{ACPD}
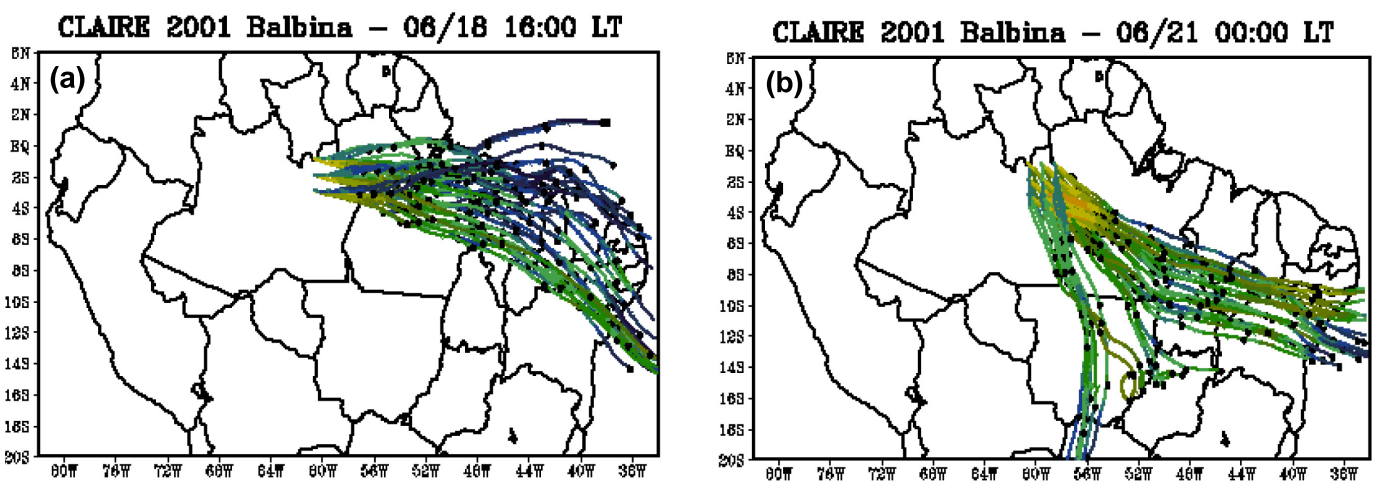

4, 2301-2331, 2004

Nitrogen oxides measurements in an Amazon site

A. M. Cordova et al.

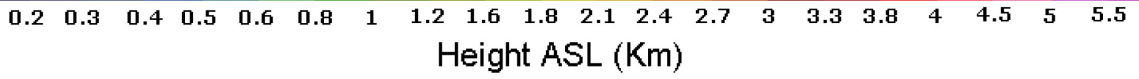

Fig. 6. Cluster of 5-day backward trajectories starting from Balbina site at (a) 18 June 2001 at 16:00 LT, and (b) 21 June 2001 at 00:00 LT.

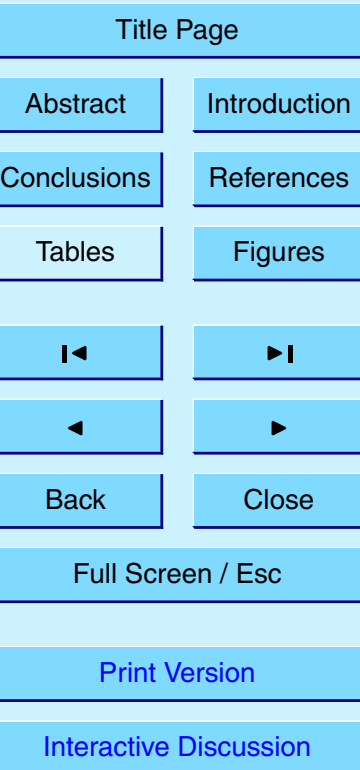

(c) EGU 2004 


\section{ACPD}

4, 2301-2331, 2004

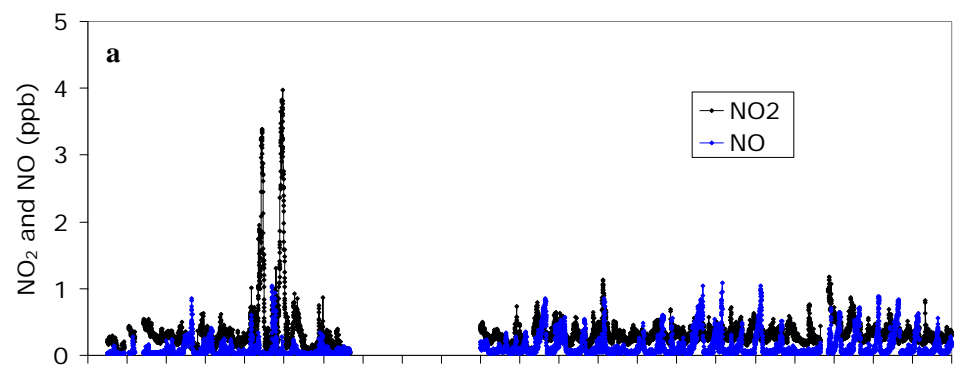

Nitrogen oxides measurements in an Amazon site

A. M. Cordova et al.
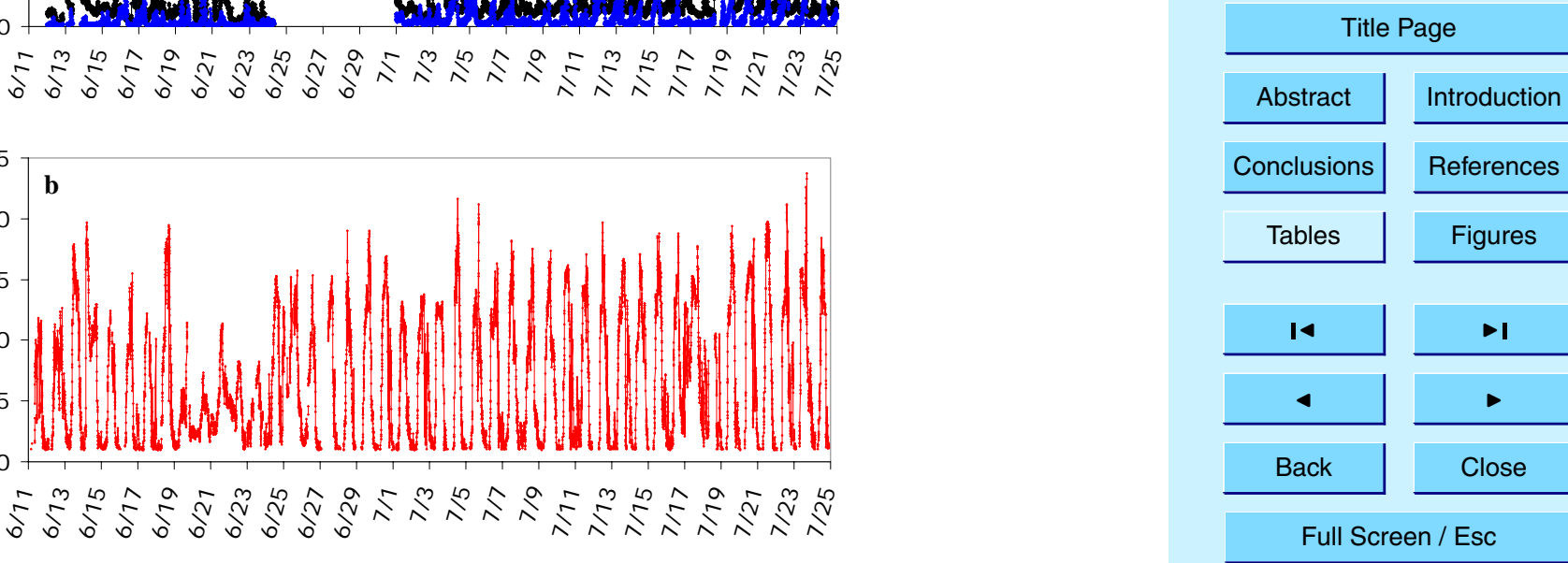

Fig. 7. Time series of (a) $\mathrm{NO}$ and $\mathrm{NO}_{2}$ and (b) $\mathrm{O}_{3}$ concentrations (ppb) measured from 12 June to 25 July 2001 during LBA-CLAIRE 2001.

Print Version

Interactive Discussion

(C) EGU 2004 


\section{ACPD}

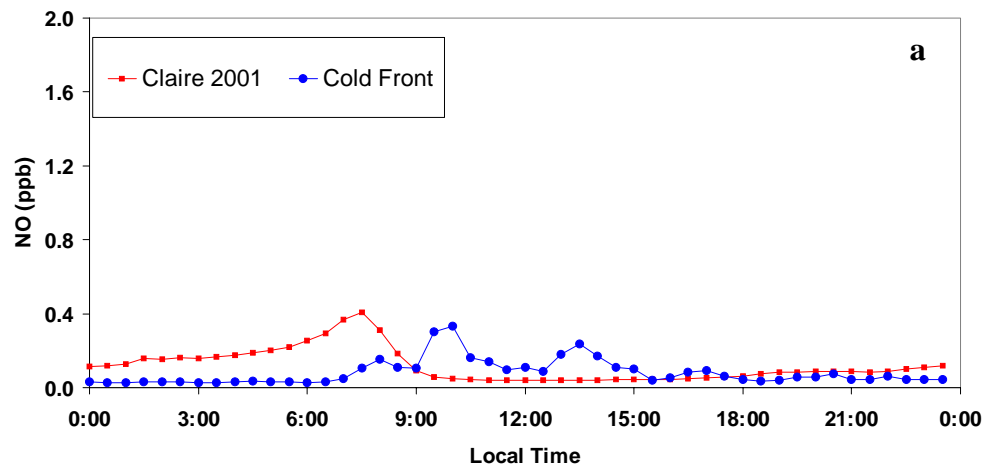

4, 2301-2331, 2004

Nitrogen oxides measurements in an Amazon site

A. M. Cordova et al.
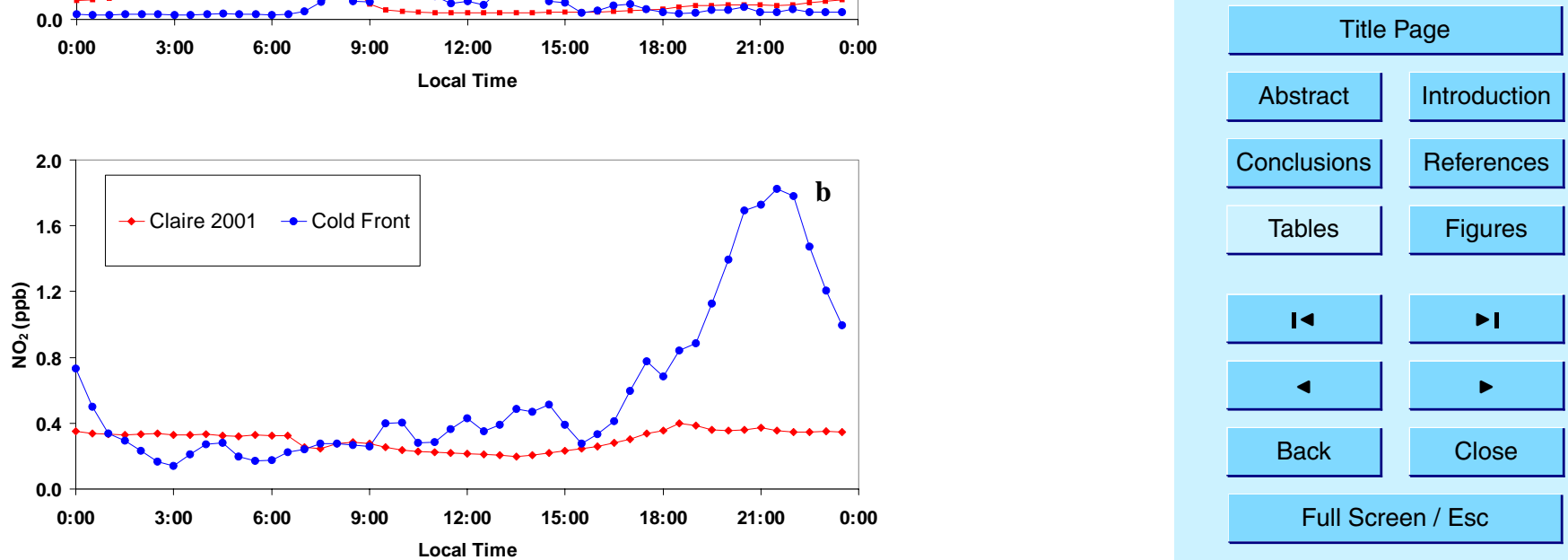

Fig. 8. Average (a) $\mathrm{NO}$ and (b) $\mathrm{NO}_{2}$ concentrations for CLAIRE 2001 and cold front periods rint Version measured in Balbina during LBA-CLAIRE 2001.

(C) EGU 2004 


\section{ACPD}

4, 2301-2331, 2004

Nitrogen oxides measurements in an Amazon site

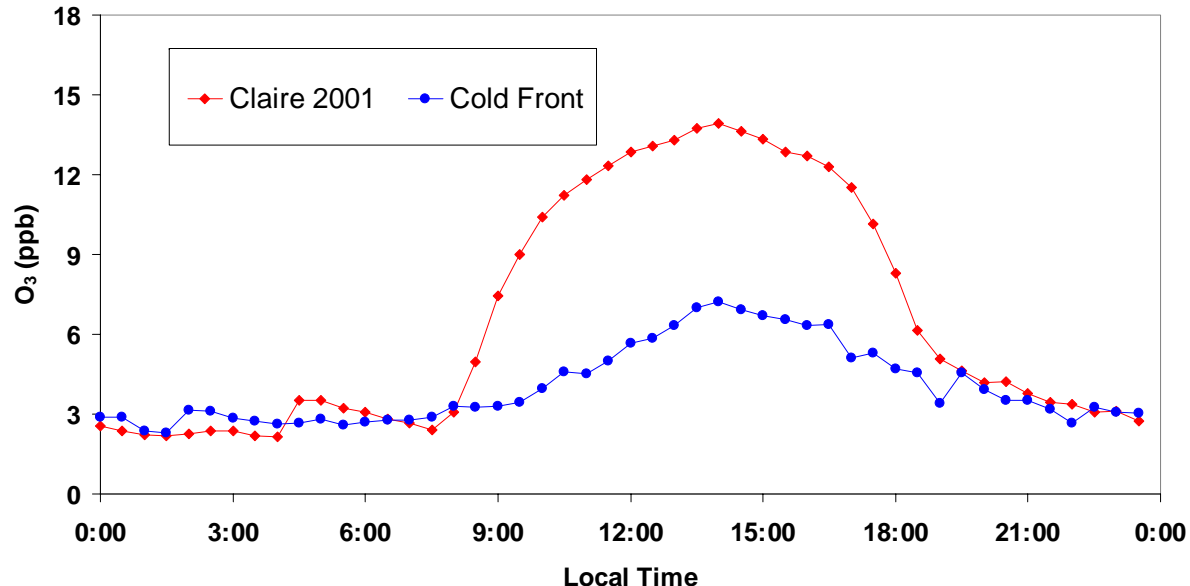

A. M. Cordova et al.

\begin{tabular}{c|c}
\multicolumn{2}{c}{ Title Page } \\
\hline Abstract & Introduction \\
\cline { 1 - 1 } Conclusions & References \\
\cline { 1 - 1 } Tables & Figures \\
\hline
\end{tabular}

Fig. 9. Average $\mathrm{O}_{3}$ concentration for CLAIRE 2001 and cold front periods measured in Balbina during LBA-CLAIRE 2001.

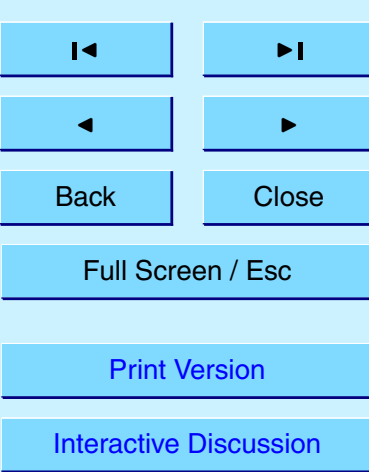

(C) EGU 2004 


\section{ACPD}

4, 2301-2331, 2004

Nitrogen oxides measurements in an Amazon site

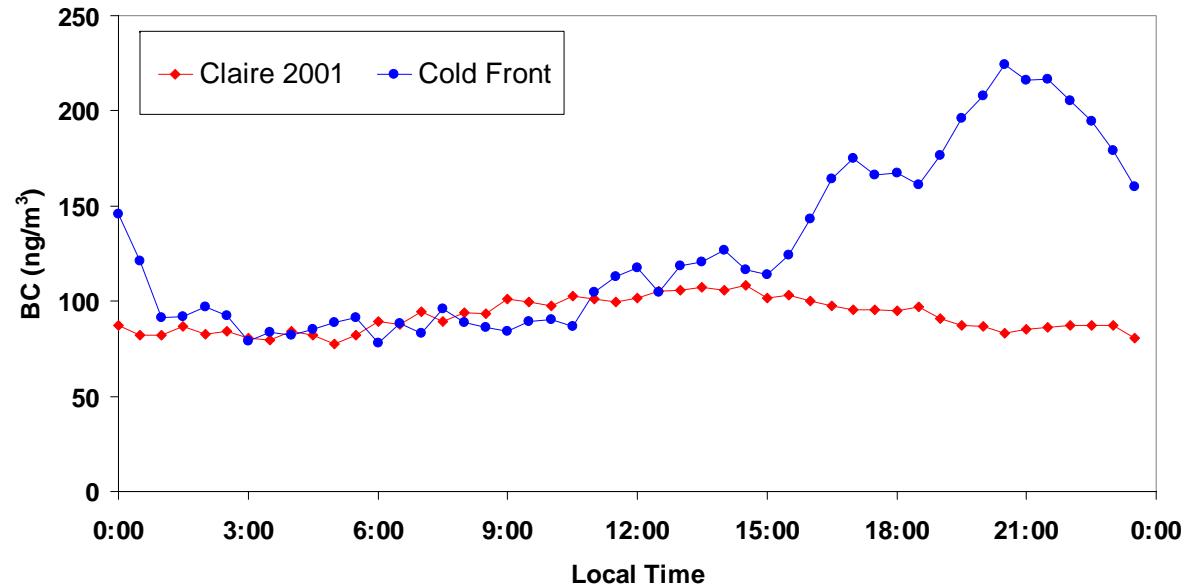

Fig. 10. Average black carbon (BC) for CLAIRE 2001 and cold front periods measured in Balbina during LBA-CLAIRE 2001.
A. M. Cordova et al.

\begin{tabular}{|c|c|}
\hline \multicolumn{2}{|c|}{ Title Page } \\
\hline Abstract & Introduction \\
\hline Conclusions & References \\
\hline Tables & Figures \\
\hline
\end{tabular}

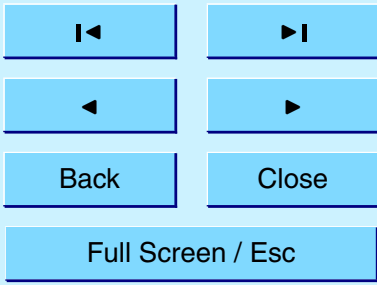

Print Version

Interactive Discussion

(C) EGU 2004 


\section{ACPD}

4, 2301-2331, 2004

Nitrogen oxides measurements in an Amazon site

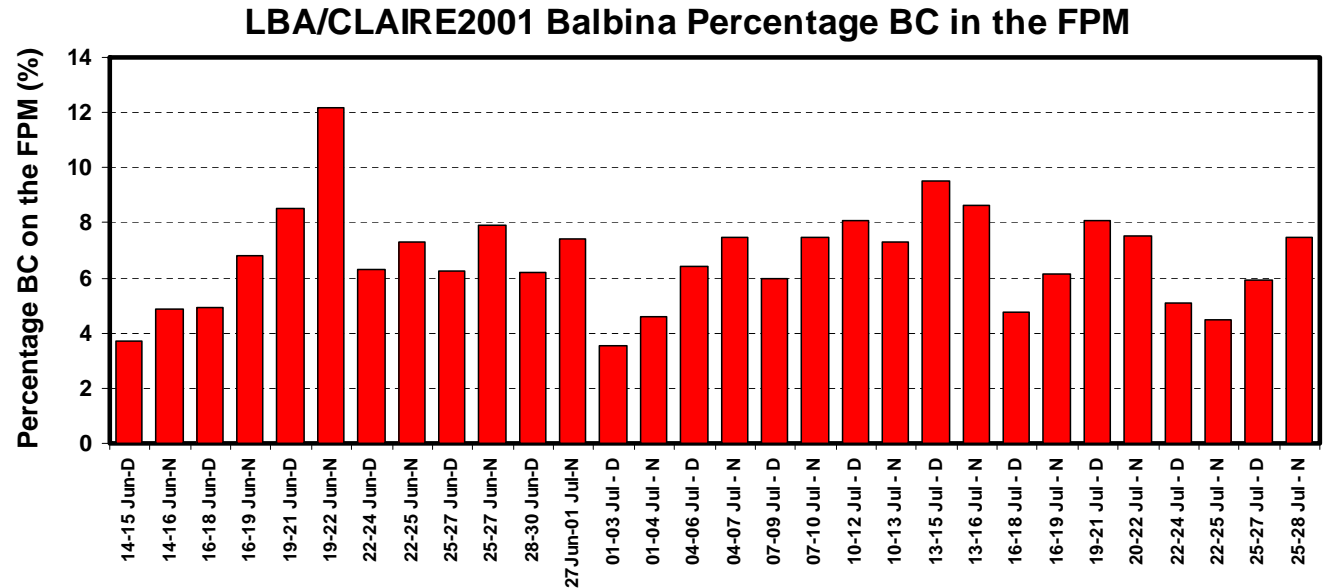

Fig. 11. Time series of black carbon percentile in the fine mode aerosol particle concentration measured in Balbina during LBA-CLAIRE 2001.
A. M. Cordova et al.

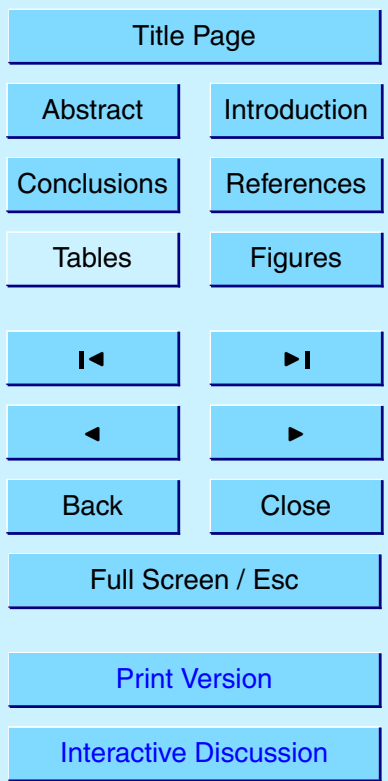

(C) EGU 2004 


\section{ACPD}

4, 2301-2331, 2004

Nitrogen oxides measurements in an Amazon site

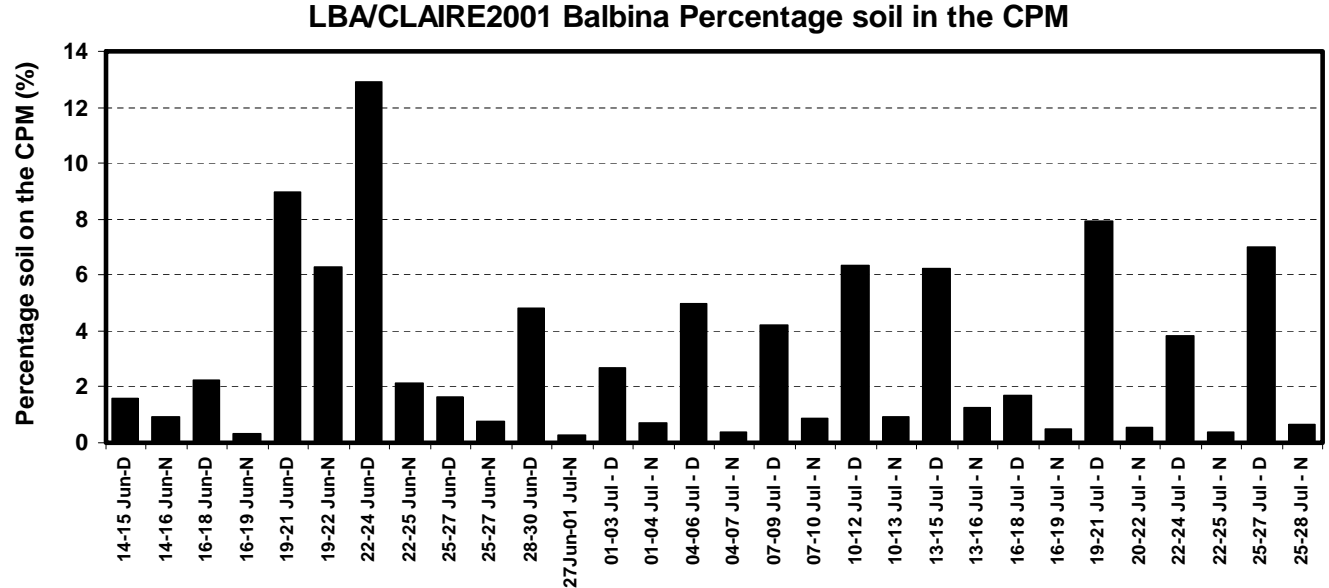

Fig. 12. Time series of soil dust percentile in the coarse mode aerosol particle concentration measured in Balbina during LBA-CLAIRE 2001.
A. M. Cordova et al.

\begin{tabular}{|c|c|}
\hline \multicolumn{2}{|c|}{ Title Page } \\
\hline Abstract & Introduction \\
\hline Conclusions & References \\
\hline Tables & Figures \\
\hline 14 & $\rightarrow 1$ \\
\hline 4 & $\triangleright$ \\
\hline Back & Close \\
\hline \multicolumn{2}{|c|}{ Full Screen / Esc } \\
\hline \multicolumn{2}{|c|}{ Print Version } \\
\hline Interactiv & iscussion \\
\hline
\end{tabular}

(C) EGU 2004 


\section{ACPD}

4, 2301-2331, 2004
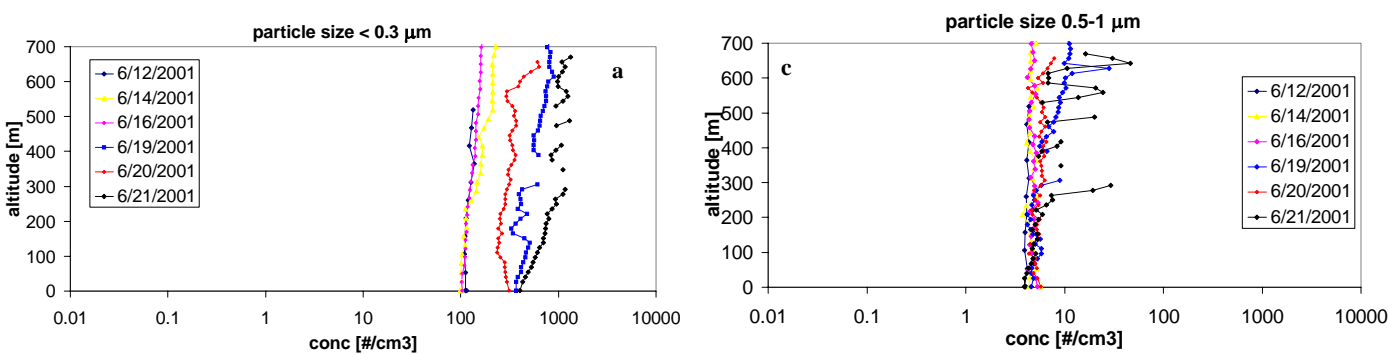

Nitrogen oxides measurements in an Amazon site

A. M. Cordova et al.
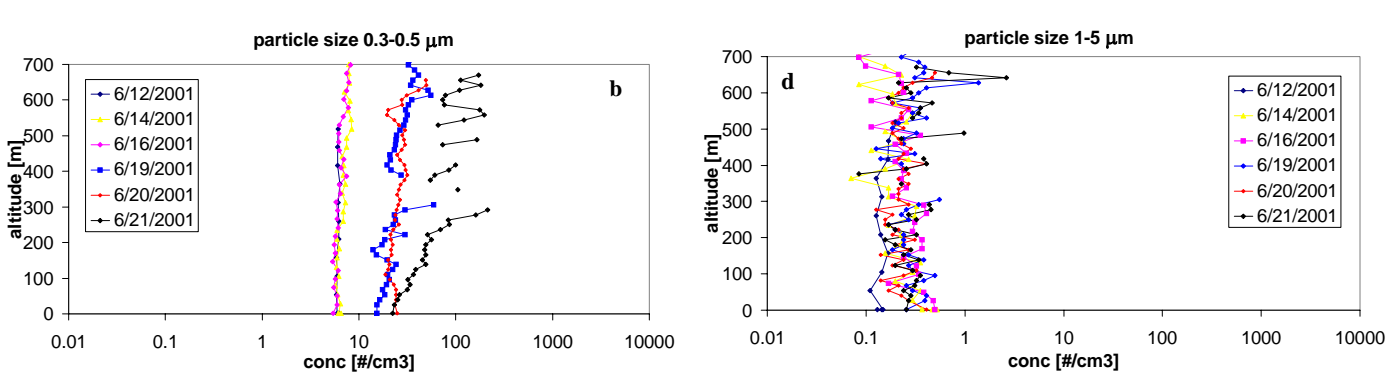

Fig. 13. Particle size vertical profiles for diameter ranges: (a) $<0.3$, (b) $0.3-0.5$, (c) $0.5-1.0$ and (d) $1.0-5.0 \mu \mathrm{m}$ for 12, 14, 16, 19, 20 and 21 June 2001, balloons launched at the Limnology Laboratory, Balbina.

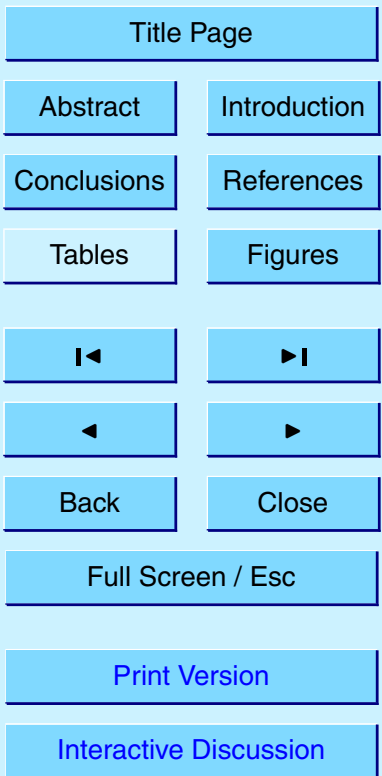

(C) EGU 2004 
GOES -8 WF_ABBA (vs 5.9) Fire Product

June 15,2001

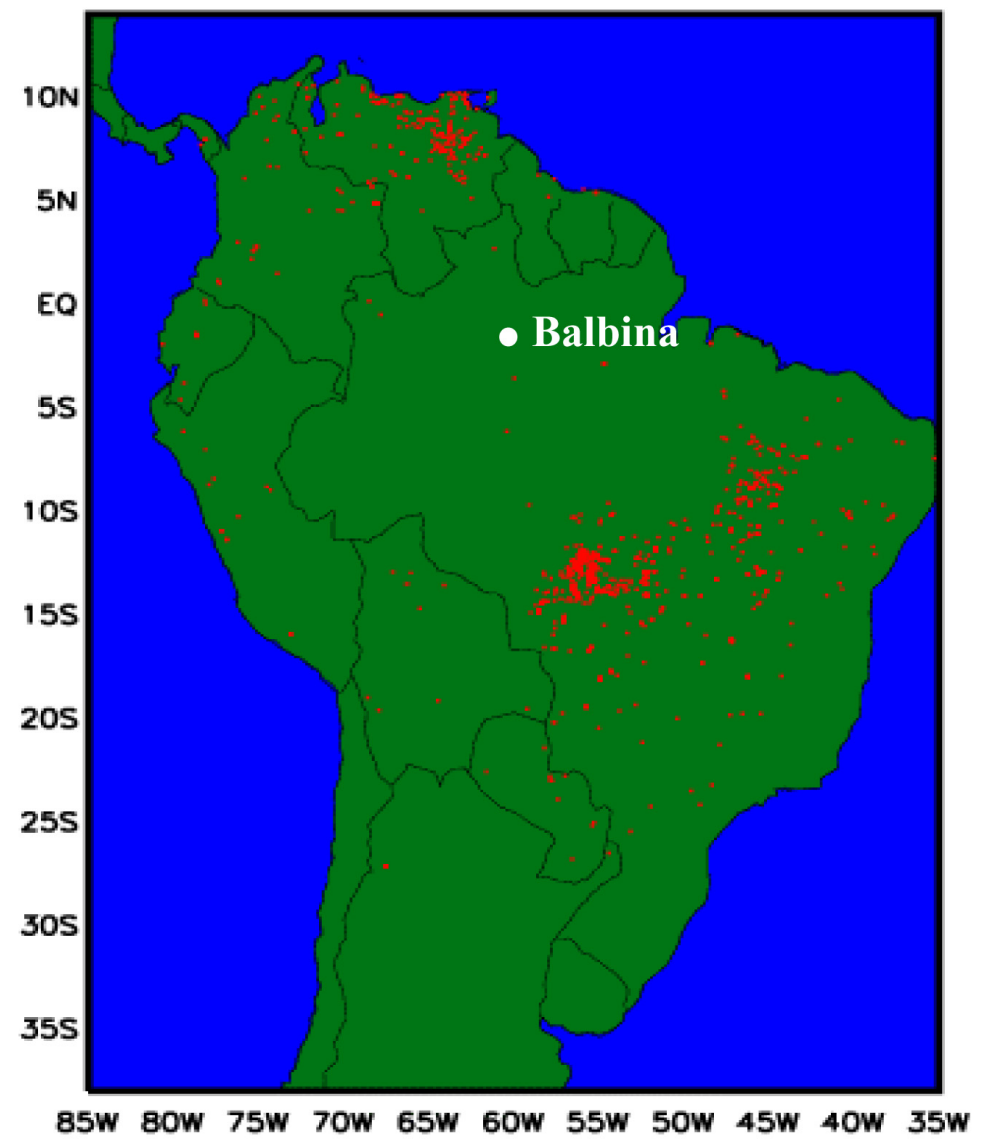

Fig. 14. Composition of GOES-8 WFABBA fire product for 15 June 2001, showing Balbina location.

\section{ACPD}

4, 2301-2331, 2004

Nitrogen oxides measurements in an Amazon site

A. M. Cordova et al.

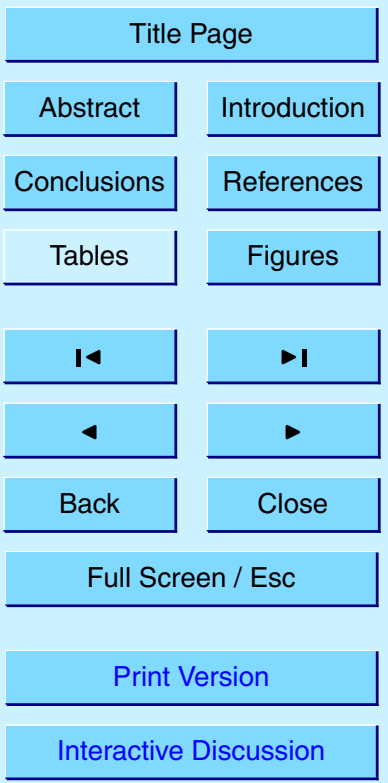

(c) EGU 2004 


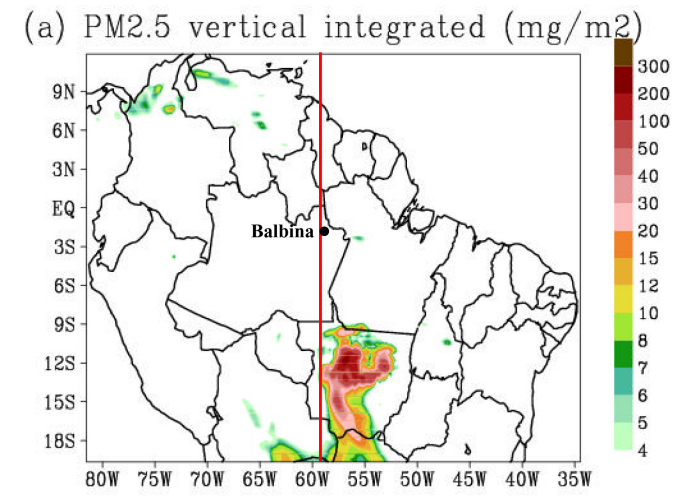

(b) PM2.5 (ug/m3) - lon 59.5W

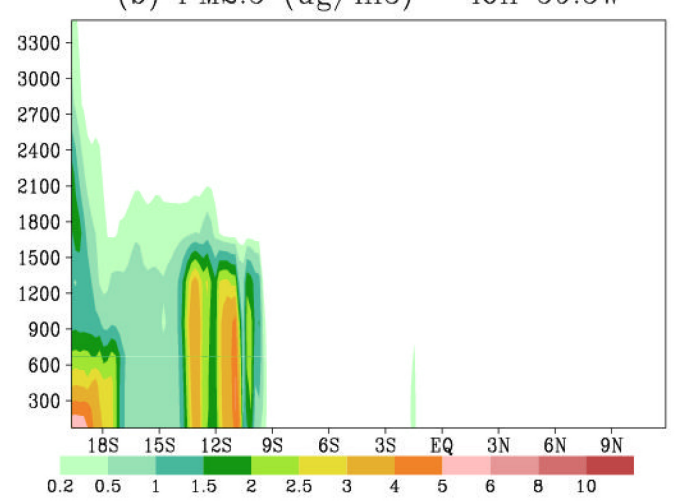

Fig. 15. (a) Particulate material from the model $(\mathrm{dp}<2.5 \mu \mathrm{m})$ vertically integrated at 16 June 2001 and (b) a vertical cross section at longitude $59.5 \mathrm{~W}$. The red line shows the cross section position.

\section{ACPD}

4, 2301-2331, 2004

Nitrogen oxides measurements in an Amazon site

A. M. Cordova et al.

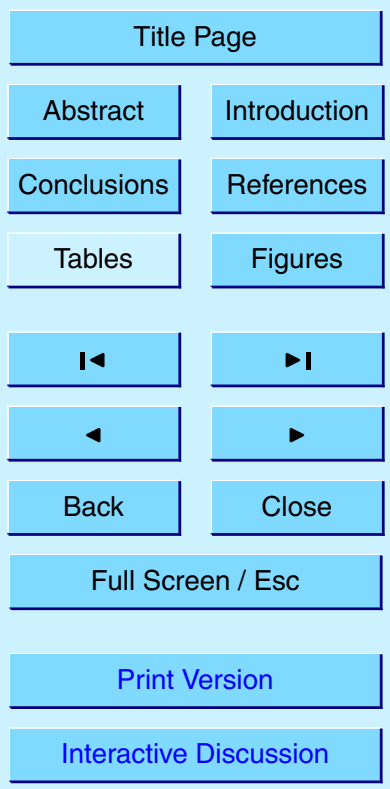

(C) EGU 2004 
(a) PM2.5 vertical integrated $(\mathrm{mg} / \mathrm{m} 2)$

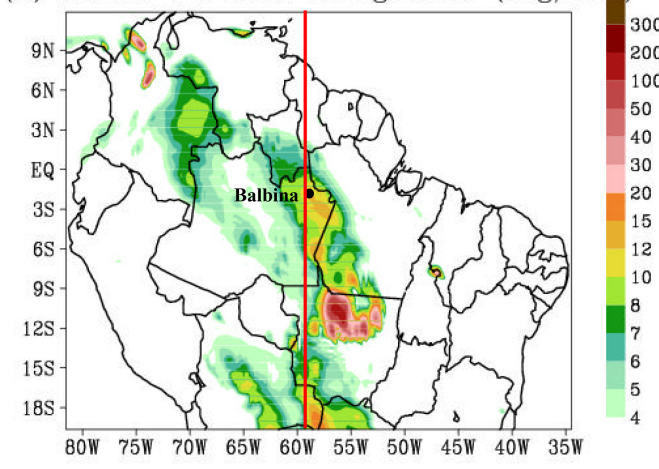

(b) PM2.5 (ug/m3) - lon 59.5W

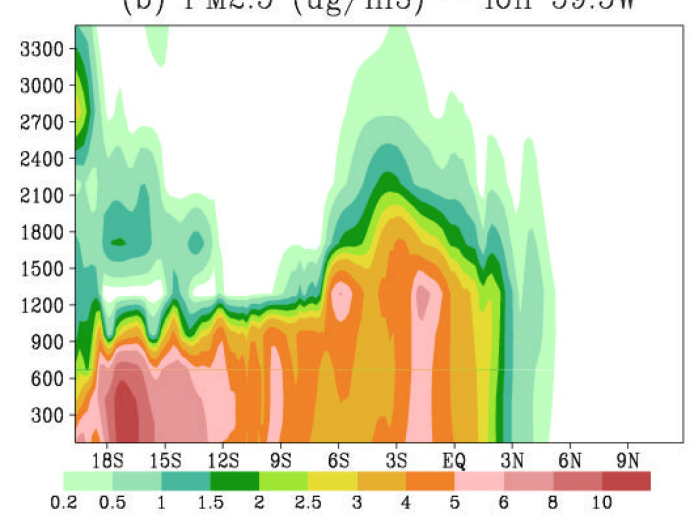

Fig. 16. (a) Particulate material ( $\mathrm{dp}<2.5 \mu \mathrm{m}, \mathrm{PM} 2.5)$ vertically integrated $\left(\mathrm{mg} / \mathrm{m}^{2}\right)$ at 21 June 2001 and (b) a vertical cross section of PM2.5 concentration $\left(\mu \mathrm{g} / \mathrm{m}^{3}\right)$ at longitude $59.5 \mathrm{~W}$. The red line shows the cross section position.

\section{ACPD}

4, 2301-2331, 2004

Nitrogen oxides measurements in an Amazon site

A. M. Cordova et al.

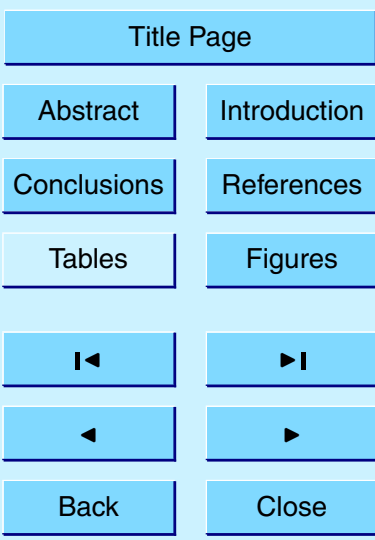

Full Screen / Esc

Print Version

Interactive Discussion

(C) EGU 2004 